\title{
Successful Prevention of Antimicrobial Resistance in Animals-A Retrospective Country Case Study of Sweden
}

\author{
Martin Wierup ${ }^{1, *}$, Helene Wahlström ${ }^{2,+}$ and Björn Bengtsson ${ }^{2}(\mathbb{D}$ \\ 1 Department of Biomedical Sciences and Veterinary Public Health, Swedish University of Agricultural \\ Sciences (SLU), 75007 Uppsala, Sweden \\ 2 National Veterinary Institute (SVA), 75189 Uppsala, Sweden; helen.wahlstrom@gmail.com (H.W.); \\ bjorn.bengtsson@sva.se (B.B.) \\ * Correspondence: martin.wierup@slu.se \\ + Retired.
}

check for updates

Citation: Wierup, M.; Wahlström, H.; Bengtsson, B. Successful Prevention of Antimicrobial Resistance in Animals-A Retrospective Country Case Study of Sweden. Antibiotics 2021, 10, 129. https://doi.org/ 10.3390/antibiotics10020129

Academic Editor: Gernot Zarfel

Received: 28 December 2020

Accepted: 25 January 2021

Published: 29 January 2021

Publisher's Note: MDPI stays neutral with regard to jurisdictional claims in published maps and institutional affiliations.

Copyright: (c) 2021 by the authors. Licensee MDPI, Basel, Switzerland. This article is an open access article distributed under the terms and conditions of the Creative Commons Attribution (CC BY) license (https:/ / creativecommons.org/licenses/by/ $4.0 /)$.

\begin{abstract}
The misuse and overuse of antibiotics have resulted in an alarmingly high prevalence of antimicrobial resistance (AMR) in human and animal bacteria. European monitoring programmes show that AMR occurrence in food animals is lower in Sweden than in most other EU Member States and that the use of antibiotics for animals is among the lowest in Europe. In this retrospective country case study, we analysed published documents to identify factors contributing to this favourable situation. A fundamental factor identified was early insight into and sustained awareness of the risks of AMR and the need for the prudent use of antibiotics. Early and continuous access to data on antibiotic use and AMR made it possible to focus activities on areas of concern. Another factor identified was the long-term control and eradication of infectious animal diseases, including coordinated activities against endemic diseases, which reduced the need to use antibiotics. Structures and strategies for that purpose established at the national level have since proven useful in counteracting AMR as an integral part of disease prevention and control, guided by a "prevention is better than cure" approach. A third factor identified was consensus among stakeholders on the need to address $\mathrm{AMR}$ and their cooperation in the design and implementation of measures.
\end{abstract}

Keywords: veterinary medicine; food animal production; antimicrobial resistance; antimicrobial use; disease prevention; disease eradication; antimicrobial growth promoters; organised health control; policies and guidelines

\section{Introduction}

The misuse and overuse of antibiotics have accelerated the development and emergence of antibiotic resistance (AMR) and resulted in an alarmingly high prevalence of AMR in human and animal bacteria [1]. To avert a crisis, in 2015, the World Health Organization (WHO) adopted a Global Action Plan on AMR to reduce the incidence of infections through disease prevention measures and to optimise the use of antibiotics in humans and animals [1]. Resistant bacteria circulating in animal populations threaten both animal and human health, so multi-sector collaboration between relevant sectors is required, as reflected by the tripartite collaboration on AMR agreed in the Global Action Plan by the Food and Agriculture Organisation (FAO), World Organisation for Animal Health (OIE) and $\mathrm{WHO}[2]$.

Recognition of the risks associated with the use of antibiotics in food animals, in particular, the use of antibiotics for growth promotion (AGP), began to emerge in the 1960s [3]. Some 30 years later, the global focus turned to AMR in food animals [4]. In 1997, the WHO recommended banning the use of AGPs [5] and formulated global principles for the containment of AMR, including the monitoring of AMR and antibiotic usage [6,7]. Shortly thereafter, the European Union (EU) decided to phase out the use of AGPs by 2006 [8] and initiated the monitoring of AMR in bacteria from animals in 2003 [9] and of 
antibiotic sales for animals in 2010 [10]. These monitoring programmes have shown that the use of antibiotics in animals is lower in Sweden than in other EU Member States [11] and that the occurrence of AMR in Sweden is among the lowest in Europe [12].

As postulated in the EU One Health Action Plan against AMR [13], lessons learnt from successful strategies in individual Member States could be valuable for other countries and support the objectives of the WHO action plan [1]; the aim of this paper was to identify those key factors that have contributed to the current favourable situation in Sweden.

\section{Food Animal Production}

Over recent decades, animal production has undergone a dramatic change in terms of mechanization, automation and management along with improvements of the animal genetic capacity and feed efficiency. This has resulted in a decrease in the number of farms producing food animals along with an increase in herd size, as summarized here for the three major production sectors in Sweden.

In dairy production, the number of farms in Sweden producing food animals has decreased, while the herd size on the remaining farms has increased. For example, the number of dairy herds has decreased by around 99\% during the past 70 years, from approximately 307,000 in 1951 to 3477 in 2018 (Figure 1).

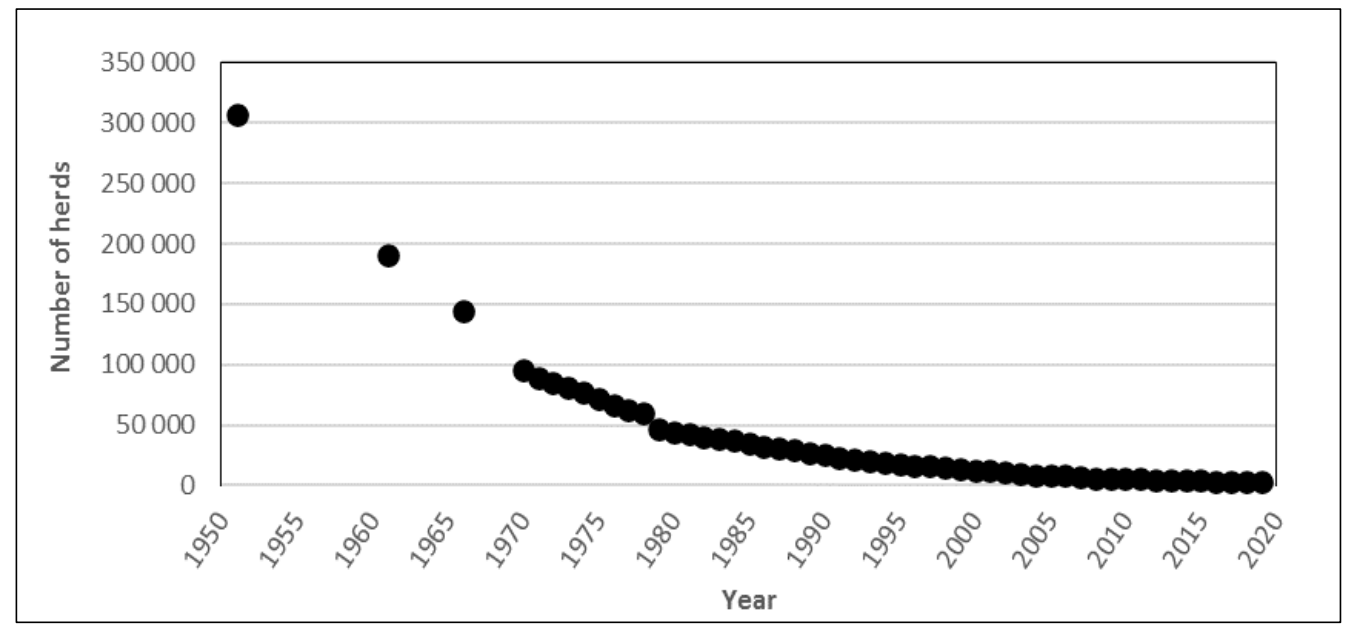

Figure 1. Numbers of cattle herds (1951-1978) and dairy herds (1979-2018) in Sweden. Data from the Swedish Board of Agriculture [14]. The data for 1951-1978 include all types of cattle herds, but the majority of farms in that period can be assumed to have had milking cows, i.e., to have been dairy herds.

During the same period, the number of dairy cattle decreased by about $80 \%(1,564,000$ in 1951 to 319,387 in 2018), but due to a higher yield per cow, Swedish milk production has only decreased by about 31\% [14]. During the past 40 years, the average milk yield per cow per year has increased from about 5000 to 8900 L [15], and dairy production in Sweden is currently among the top performers in Europe [16]. The average herd size increased from about 14.1 cows per herd in 1979 to 91.9 in 2018 (Figure 2).

The most recent change towards larger dairy herds has occurred in herds with $>199$ cows, which are increasing in number, whereas the number of herds with fewer than 99 cows is decreasing. (Figure 3). 


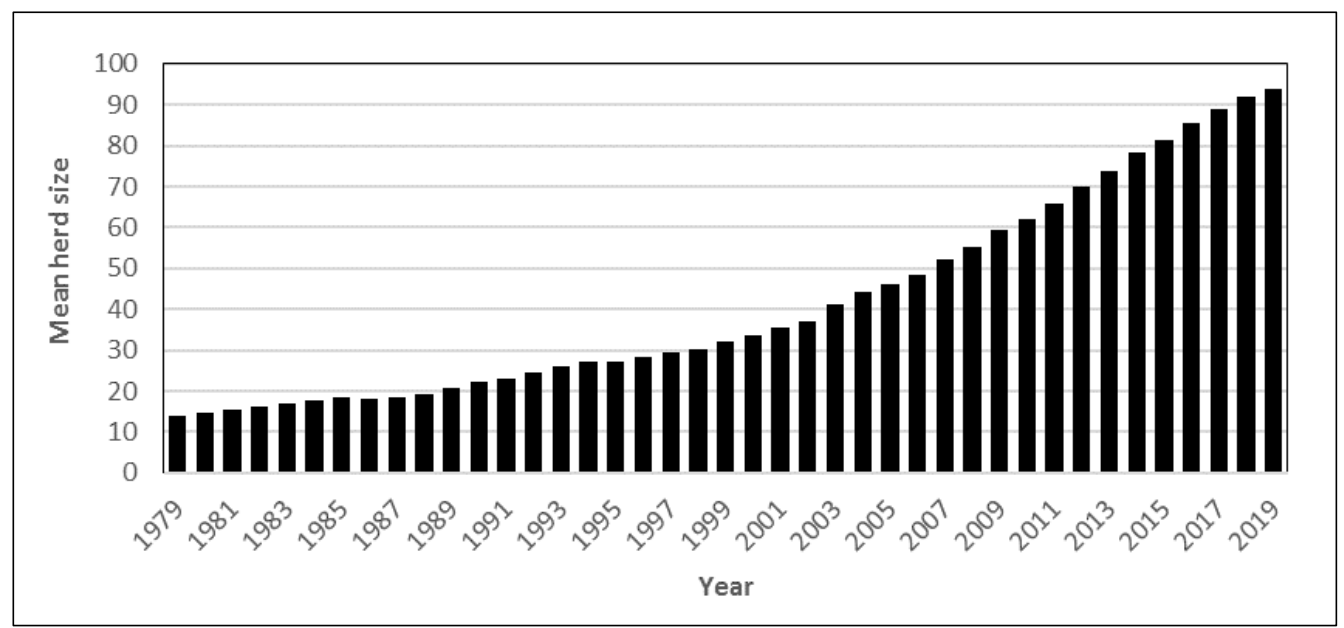

Figure 2. Mean dairy herd size for 1979-2018 in Sweden. Data from the Swedish Board of Agriculture [14].

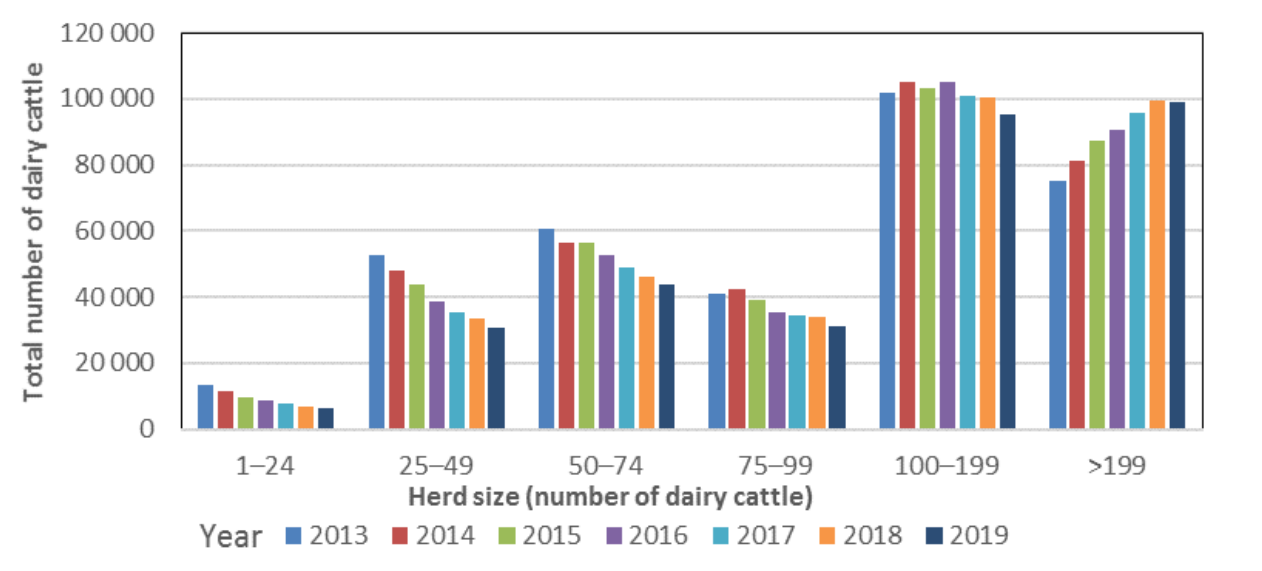

Figure 3. Number of dairy cattle in different herd size categories for 2013-2018 in Sweden. Data from the Swedish Board of Agriculture [14].

Total pig production in Sweden increased from about 90,000 tons of meat in 1945 to 330,000 tons during the 1980s-1990s, and then decreased to the current (2019) 250,000 tons, with about 2.5 million pigs slaughtered annually [14]. The number of pig farms decreased from 350,000 in 1925 to 1300 in 2018 [14]. Key data on production efficiency in 2019 in controlled Swedish herds show an average daily weight gain for fattening pigs of $948 \mathrm{~g}$, with 27.1 piglets produced per sow and year [17].

The largest change in the food animal sector has been in poultry production, where the level today is eight times higher than in the 1950s [18]. Commercial broiler production increased from 74,000 tons in 1995 to 158,000 tons in 2019 [14], and in 2018, a total of 98.5 million broiler chickens were produced [19]. As seen for milk and pig production, the size of poultry farms has increased and, for commercial broiler production, the number of farms has also increased [19].

\section{Summary of Key Factors}

Food animal production in Sweden has undergone structural changes, with the concentration of production in larger units and high productivity from an international perspective. 


\section{Prevention and Control of Infectious Diseases}

\subsection{Diseases Controlled by National Authorities}

\subsubsection{Major Epizootic Diseases}

During the 18th-20th centuries, Sweden frequently experienced outbreaks of major epizootic diseases, which in general, were effectively controlled by national authorities [20]. In addition to the major outbreaks listed in Table 1 and outbreaks of rinderpest, contagious bovine pleuropneumonia, rabies and anthrax, Swedish authorities were early in legally defining other disease outbreaks as epizootic and accordingly controlled them in the same powerful way, aiming for disease freedom. These diseases included bovine genital campylobacteriosis, fowl typhoid and pullorum disease (Salmonella Gallinarum and S. Pullorum) [20].

Table 1. Significant outbreaks of major epizootic diseases in Sweden for 1900-2020. Adapted from Cerenius [20], National Veterinary Institute (SVA) [21] and [22].

\begin{tabular}{|c|c|c|c|}
\hline Year & Disease & Animal Species & Comments \\
\hline $1924-27$ & Foot and mouth disease (FMD) & Cattle & 11,002 herds infected. \\
\hline $1938-40$ & FMD & Cattle & 7293 herds infected. \\
\hline 1940 & Classical swine fever (CSF) & Pigs & 230 herds infected. \\
\hline $1943-44$ & CSF & Pigs & 445 herds infected. \\
\hline $1950-56$ & Paratuberculosis & Cattle & Beef cattle, 830 animals seropositive. \\
\hline $1951-52$ & FMD & Cattle & 562 herds, 1 million cattle vaccinated. \\
\hline 1953 & Salmonella epidemic & Several, mainly cattle & 9000 human cases, 90 deaths. \\
\hline $1956-57$ & Porcine brucellosis & Pigs & 76 herds infected. \\
\hline $1956-57$ & Anthrax & Cattle/pigs & 19 cattle herds / 68 pig herds infected. \\
\hline 1960 & FMD & Cattle & 6 herds infected. \\
\hline 1993 & Paratuberculosis & Cattle & 53 beef cattle herds infected. \\
\hline 1991-97 & Bovine tuberculosis & Farmed deer & 13 herds infected. \\
\hline 1995-96 & Newcastle disease (ND) & Poultry & $\begin{array}{l}650 \text { flocks tested; } 1.75 \text { million birds/eggs } \\
\text { destroyed. }\end{array}$ \\
\hline 2007 & $\begin{array}{l}\text { Porcine reproductive and } \\
\text { respiratory syndrome (PRRS) }\end{array}$ & Pigs & 7 herds infected, modified stamping out. \\
\hline $2008-09$ & Bluetongue & Cattle & $\begin{array}{l}30 \text { outbreaks in different regions, } \\
2.7 \text { million cattle vaccinated. }\end{array}$ \\
\hline $2010-20$ & $\begin{array}{l}\text { Highly pathogenic avian } \\
\text { influenza and ND }\end{array}$ & Poultry & 2 and 5 outbreaks, respectively. \\
\hline $2010-20$ & Anthrax & Cattle & 12 outbreaks. \\
\hline
\end{tabular}

The eradication of bovine tuberculosis (bTB) and bovine brucellosis required substantial long-term efforts. Both diseases were probably introduced by early imports of infected breeding animals during the middle of the 19th century or earlier and became widespread. In 1937, 30\% of the cattle slaughtered in southern Sweden had macroscopic lesions of tuberculosis [23], while in 1944, 16,000 (6\%) of the cattle herds in Sweden were infected with bovine brucellosis [24]. During the period 1897-1933, bTB was controlled by a low-intensity and mainly unsuccessful control programme based on tuberculin tests, but in 1934, the control was extended to a national eradication programme, and Sweden was declared free from bTB in 1958 [25]. Efforts to eradicate bovine brucellosis were started in 1944, based on nationwide monitoring using the Abortus Bang Ring Test, and by 1962, the infection was eradicated [24]. As part of these eradication programmes, a nationwide 
network of veterinary laboratories was built, which facilitated the subsequent control of other diseases (see below).

\subsubsection{Salmonella}

The early initiation of Salmonella control by national authorities in Sweden more than 60 years ago is unique from an international perspective because zero tolerance for Salmonella in the whole feed-to-food chain was applied from the start. The control of Salmonella is therefore described in more detail here.

Animals: In 1953, S. Typhimurium spread from a domestic slaughterhouse in Sweden and caused the death of 90 people and more than 9000 cases of illness [26]. In another outbreak, 500 people were infected by meat imported from South America [27]. These outbreaks of salmonellosis in humans highlighted the need to control Salmonella, which was enforced by Swedish regulations in 1961 [28]. Thereby, findings of Salmonella from animals, humans, feed or food were made notifiable to the authorities. Infected herds are subject to restrictions until the infection has been eradicated, but the use of antibiotics to clear farms of infection is not permitted [21,29].

In poultry production, the control of Salmonella is stricter, and flocks infected with any serovar of Salmonella are destroyed. In broiler production, a voluntary control programme run by the authorities, including the pre-slaughter testing of flocks, was initiated in 1970 [30]. The programme became mandatory in 1984 [31]. In order to avoid possible Salmonella contamination in broiler abattoirs, in 1991, the broiler industry introduced the pre-slaughter testing of laying hens [20]. This was later included in a voluntary control system in layer production, in response to the pandemic spread of $S$. Enteritidis in the late 1980s [32] and became mandatory in 1994 [33]. Currently, all commercial poultry production is under control for Salmonella [21,29].

Feed: The control of Salmonella in feed was initiated as a voluntary programme run by the industry in 1958, when the assessment of outbreaks of anthrax from imported meat and bone meal also frequently revealed simultaneous contamination with Salmonella [34]. The programme was later extended to the bacteriological testing of other risk ingredients such as soy and rape meal, heat treatment of poultry feed (1972) and testing of all nonheat-treated feed (1987), and in 1991, HACCP-based control of the whole production chain was implemented [20]. The voluntary control became compulsory in 1993 [35], and under current legislation, crushing plants and feed mills must be closed for decontamination upon any detection of Salmonella on the "clean side" [36]. The control of Salmonella in feed production, including imported feed ingredients, most certainly prevented the introduction of this pathogen into animal production [37]. This control, and that on imported breeding animals (see below), is considered to have prevented the introduction of $S$. Enteritidis into Swedish poultry production during its pandemic spread in the late 1980s [32].

Food: Food of animal origin contaminated by any serovar of Salmonella is considered unfit for human consumption, and in 1971, this was formalised in national legislation [38]. This zero tolerance of any contamination by Salmonella, in particular, of carcasses after slaughter, is considered to have contributed to compliance with the pre-harvest control of Salmonella.

\subsection{Diseases Controlled by the Industry}

The introduction of more intensive and specialized food animal production processes increased health disorders caused by endemic diseases, mainly respiratory infections. Trade in animals, especially to specialist and large-scale production units, was identified as a risk factor. The pig industry, therefore, established a health advisory veterinary organisation to prevent these infections as early as 1945, and provided health counselling services (here referred to as health control) as a complement to the conventional treatment of sick animals mainly performed by officially employed district veterinary officers [39]. The laboratory facilities established in all regions of Sweden for the eradication of bTB and bovine brucellosis also had sufficient capacity for providing diagnostic services for health 
control. A basic task for health control in pig production was to certify herds permitted to sell live animals on the market, with the mandate to withdraw certification in the case of health problems. In 1954, the Swedish dairy sector established a corresponding health control for bovine mastitis [20], and health controls were later introduced in the beef and sheep sectors [39]. It is estimated that today, close to $100 \%$ of all commercial dairy, pig and poultry producers in Sweden participate in such health controls.

\subsubsection{Organised Health Controls}

Following an inquiry by the national veterinary services in the late 1960s [40], a parliamentary decision in 1969 clarified that the industry should be financially responsible for health controls. Prior to that decision, health controls, including the laboratory diagnostic support described above, were subsidised by the state. However, an act on the control of animal diseases established the concept of organised health control. The aim was to control specific diseases and health issues of national importance, and organised health controls were therefore eligible for state financial support. The concept was specified as follows: "The state, through a trusting collaboration with the industry, can make the control work so that it also benefits the state" [40]. The organised health control system initiated is managed by the industry and led by a control organisation, usually the veterinary organisation affiliated with the cooperative slaughterhouses or dairy associations. The organised health controls follow rules approved by the Swedish Board of Agriculture, the supervising authority. According to the current legislation [41], the aim of this voluntary control is to "stop or prevent the spread of infections and diseases and to improve the health of farm animals". All producers can join and must be treated equally by the control organisation, for example, regardless of whether they are linked to a cooperative or private slaughterhouse, which commonly competes in the red meat sector. To achieve joint action by affiliated farmers, each organised health control has a steering committee representing all key stakeholders and the supervising authority. This structure facilitates compliance with the control and the final eradication of a disease, for example, by preventing individual producers from delivering animals to slaughter or milk to dairies if they refuse to follow the rules or join the control [42].

The organised health controls have proven to be an efficient tool for preventing and controlling diseases. A major focus was to limit risks related to the trade of animals. Examples of infections for which organised health controls were implemented for control or eradication are given in Table 2.

Table 2. Examples of infectious diseases eradicated (recognized free by EU) or brought under control by organised health controls in Sweden [21,43].

\begin{tabular}{|c|c|c|c|}
\hline Year & Disease & Animal Species & Comment \\
\hline 1990-2001 & Enzootic bovine leucosis (EBL) & Cattle & Initially, $25 \%$ of dairy herds infected. Eradicated. \\
\hline $1991-1996$ & Aujeszky's disease (AD) & Pigs & Initially, $5 \%$ of sow herds infected. Eradicated. \\
\hline 1993-2013 & Bovine viral diarrhoea (BVDV) & Cattle & $\begin{array}{l}\text { Initially, } 40 \% \text { herd prevalence. Nationally declared } \\
\text { freedom in } 2014 .\end{array}$ \\
\hline $1993-$ & Maedi-Visna (MV) & Sheep & $\begin{array}{l}\text { Initially, } 8.2 \% \text { herd prevalence. Ensure disease-free herds } \\
\text { for livestock trade. }\end{array}$ \\
\hline 1994-1998 & Infectious bovine rhinotracheitis (IBR) & Cattle & Initially, $0.2 \%$ of dairy herds seropositive. Eradicated. \\
\hline 1998-2017 & Paratuberculosis & Cattle & $\begin{array}{l}\text { Repeated introduction in beef cattle after imports; latest } \\
\text { case in } 2005 \text {. Dairy herds never infected. Surveillance to } \\
\text { document a very low prevalence or possibly declare } \\
\text { national freedom. }\end{array}$ \\
\hline 1998- & $\begin{array}{l}\text { Porcine reproductive and respiratory } \\
\text { syndrome (PRRS) }\end{array}$ & Pigs & $\begin{array}{l}\text { One outbreak in } 2007 \text {. Freedom nationally redeclared } \\
\text { in } 2008 .\end{array}$ \\
\hline $1993-$ & Campylobacter spp. & Broilers & Surveillance aiming at reducing prevalence. \\
\hline
\end{tabular}


Hygiene and biosecurity routines on farms, in aquaculture and in feed production are important components of disease prevention. These routines were initially implemented as a spin-off effect from the eradication and control of specific diseases, such as bTB, bovine brucellosis, infectious bovine rhinotracheitis and enzootic bovine leucosis in the dairy sector; Aujeszky's disease in the pig sector; and Salmonella in all food animal and feed production. These measures have, for example, eliminated the need for vaccination against the most commonly occurring viral infections in broiler production [44].

Implementing new scientific achievements and surveillance procedures has, in several cases, been essential for the introduction of organised health controls and eradication programmes. For example, the eradication of enzootic bovine leucosis (EBL) was facilitated by the introduction of a bulk milk test method [45], which to date, has been applied for several other viral infections and also parasitic diseases [46], and the use of the DIVA vaccine, which allows for the immunological differentiation of infected from vaccinated animals, facilitated the eradication of Aujeszky's disease (AD) [47].

\subsubsection{Organised Health Services}

In addition to the organised health controls described above, the industry continues to provide health counselling services, hereafter referred to as organised health services, which are fully financed by the industry. In the respective production sectors, both activities are carried out in an integrated way by the same veterinary organisations. The organised health services focus on infections and health disorders not covered by the organised health controls. They include annual visits to affiliated producers/farms by specialist veterinarians and visits upon call for actions to control herd health problems. In pig production, major improvements in health status have been achieved for traditionally dominant infections such as atrophic rhinitis [21], E. coli-related piglet diarrhoea [48] and swine dysentery [49], which have been eliminated as major problems. The same applies to Salmonella in all food animals, due to the zero-tolerance policy described above [21]. Considerable improvements in health status have also been achieved in the dairy sector [50] and the poultry sector $[44,51]$.

The organised health services are also tasked with supporting the official surveillance of different infectious diseases [21] and other animal health projects, including on AMR, as described in annual reports to the Swedish Board of Agriculture [52].

\subsubsection{Limitation and Control of Import of and Trade in Live Animals}

The import of live animals to Sweden was identified at an early stage as a risk factor for outbreaks of major epizootic diseases and other infectious diseases, and an early national policy for the food animal sector was, therefore, to limit the import of live animals [20]. This strategy was challenged when Sweden joined the EU in 1995. To minimise the risk of introducing diseases not covered by the harmonised rules for trade in cattle, pigs, sheep and their genes (semen and embryos) within the EU, the voluntary Swedish Farmers Disease Control Programme (SDS) was introduced by the industry in 1995 [53]. During recent years, the measures have been extended to prevent the introduction of methicillinresistant Staphylococcus aureus (MRSA) in pig production [53]. Over more than 20 years of this control system, low-volume and high-biosecurity trade in live animals from abroad has been maintained [53]. In addition to SDS, corresponding voluntary measures by the Swedish Poultry Meat Association (SPMA) have been in place in the poultry sector since Sweden's accession to the EU.

The restricted import policy prevented the introduction of porcine reproductive and respiratory syndrome (PRRS) in pigs during its global spread in the late 1980s [54]. Likewise, the restricted and controlled trade in live pigs from abroad most likely mitigated the introduction of MRSA into pig production in Sweden [55]. In addition, the pre-import testing of day-old grandparent chickens in the late 1980s prevented the pandemic spread of S. Enteritidis from entering the Swedish poultry population, and has also considerably decreased the risk for the introduction of other serovars of Salmonella [32]. Voluntary 
efforts by SPMA, in cooperation with the National Veterinary Institute (SVA), have also mitigated the introduction of Escherichia coli resistant to extended-spectrum cephalosporins (ESC) in broiler production via breeding animals traded from abroad [56,57].

\subsection{Summary of Key Factors}

State veterinary leadership, veterinary infrastructure and regional veterinary laboratory capacity were established early in Sweden for the eradication of major epizootic diseases. These later became valuable tools in the prevention of other infectious diseases and facilitated the introduction in 1945 of industry-led health counselling services. The regulatory implementation of organised health controls in 1969 clarified the responsibility of the industry for disease prevention but also offered a tool for financial support from government for the control of specific diseases and other activities of national interest. This transformed the industry-led health counselling services into coordinated and focused activities. As a result, important endemic diseases were controlled or eradicated through joint action by government and the industry.

Access to veterinary expertise and regular visits by veterinarians to farms enrolled in organised health controls and organised health services provide farmers with farmspecific advice on the management and prevention of diseases and are also important for compliance with policies and recommendations on biosecurity, the use of antibiotics and good agricultural practice.

The limited and controlled import and trade in animals, genes and feed ingredients has prevented the introduction of several infectious diseases.

Hygiene and biosecurity routines on farms and in feed production were implemented early in Sweden through the control and eradication programmes.

Although not specifically described here, or found to be specifically documented, stringent animal welfare regulations are also considered to have improved animal health and decreased the need for antibiotic treatment [58]. For example, limiting the stocking density in broiler and pig production [59], weaning after 26 days of age [60], prohibiting tail docking [61] and encouraging the use of straw bedding [61,62] in pig production are considered to have promoted health. These measures are supported by opinions from the European Food Safety Authority (EFSA) on the welfare of pigs [63,64].

\section{Antibiotic Use and Resistance}

\subsection{Early and Continuous Awareness of the Problems with AMR}

The concept of AMR and the need for the prudent use of antibiotics in animals were already familiar to Swedish veterinarians in the 1950s. Numerous articles in the national veterinary journal highlighted the issue and the risk of overuse [65-70]. In 1963, a session at the annual Swedish Veterinary Conference was dedicated to antibiotic use and AMR, with a Danish keynote speaker lecturing on the pros and cons of antibiotic use in animals [71]. In subsequent years, the issue was raised again in the national veterinary journal [72-75] and also in the trade journals [76-80]. At the annual Swedish Veterinary Conference in 1973, there was a public debate on the use of antibiotics in animals [81]. In that year, a Swedish study by Jonsson and Jacobsson [82] questioned the practice of providing in-feed medication to calves, and others presented AMR from a human healthcare perspective $[83,84]$.

From the 1950s onwards, data on AMR in animal pathogens were widely presented (see below), making Swedish practitioners aware of AMR as a problem that could be encountered in everyday clinical practice (e.g., [85-89]). Further emphasis was placed on AMR as a concrete clinical problem following the documentation in the mid-1970s of transmissible resistance in E. coli from calves and pigs in Sweden [90,91]. Additional support for the discussion was provided by the first presentation of data on annual sales of antibiotics for animals (see below).

In the early antibiotic era, pharmacokinetic data on antibiotics were scarce and dosages were generally not based on hard scientific evidence. To improve the treatment of bovine 
mastitis, the distribution of penicillin to the udder was studied in Sweden as early as the 1950s [92]. Later, pharmacokinetic studies of several other antibiotics were performed [93-98]. Several of these studies questioned the dosing regimens applied, an issue specifically highlighted in a symposium held in 1981 [99-102]. In addition, therapeutic studies were performed as a basis for antibiotic treatment [103-113]. Since 1973, harmonised information (Fass Vet) on the characteristics, indications and dosages of pharmaceutical products, including antibiotics, licensed for use in animals has been compiled by the Swedish Association of the Pharmaceutical Industry (www.lif.se). Fass Vet is updated annually and distributed to all veterinarians in Sweden, electronically since 2017 (www.fass.se). The contents are approved by the competent authority (currently the Swedish Medicinal Products Agency).

\subsection{Ban on $A G P s$}

As a result of the national focus on the use of antibiotics and AMR described above, Sweden became the first country in the world to legislate on the withdrawal of antibiotics for growth promotion, and the use of AGPs was banned in 1986. At that time, AGPs were included in practically all feed for pigs and broilers in Sweden. The ban was preceded by an intensive debate in the media and the industry, and by scientific evaluations by national authorities and other stakeholders, as reviewed by Nordéus [114]. It was argued, for example, that society/consumers preferred animal production not to be dependent on the routine use of antibiotics. In response to this, the Federation of Swedish Farmers voluntarily issued a policy on the restrictive use of antibiotics in $1981[114,115]$ and requested a total ban on AGPs in 1984, following which the total national ban on AGPs came into force in 1986 [114]. The implementation and consequences of the ban on AGPs and on the sales of antibiotics were reviewed by Wierup [116]. The ban also led to an increased focus on disease prevention by means other than the use of antibiotics [117].

When Sweden joined the EU in 1995, the national ban on AGPs was challenged, and Sweden was asked by the EU to provide scientific evidence for upholding the ban. To obtain relevant evidence, a thorough review of the pros and cons of AGP use was made [118]. The evidence provided and the recommendation by the EU Scientific Steering Committee to phase out the use of AGPs [119], combined with a lobbying effort from Swedish representatives to uphold the ban, was probably an important contributing factor in the subsequent complete ban on AGPs in the EU in 2006 [120].

\subsection{Prevention and Control of Bacteria with Specific Resistance}

Efforts have also been made to directly counteract the spread of bacteria with AMR of specific importance. For example, in 1995, a policy on the treatment of mastitis in dairy cows recommended that cows infected with penicillin-resistant Staphylococcus aureus should be culled instead of treated [121]. The reduction in the occurrence of penicillinresistant S. aureus from $10 \%$ in 1985 [122] to about 1\% in recent years [123] is probably largely an effect of adherence to this recommendation. In another example, an outbreak of tiamulin-resistant Brachyspira hyodysenteriae in pig herds in 2016 was actively curbed [124]. This organism causes swine dysentery in pigs, and tiamulin is vital for treatment in affected herds. Efforts to control the spread of E. coli resistant to ESC in broiler production and MRSA in pig production by the control of imported animals are other examples of work to contain specific types of resistance.

Legislative efforts are also in place to mitigate the spread of bacteria with specific resistance, with the detection of methicillin-resistant coagulase-positive Staphylococci (MRS) and carbapenemase-producing Enterobacteriaceae (CPE) in animals being made notifiable in 2008 and 2012, respectively [125]. Complementary legislation in 2013 [126] defined the management of MRS cases in cats, dogs and horses and made provisions for infection prevention control plans in veterinary practices. The legislation was accompanied by recommendations from the Swedish Veterinary Association (SVF) [127]. The impact of 
these measures is evident in the fact that CPE has not been detected in animals in Sweden and that the situation regarding MRS is favourable [128].

\subsection{Access to Data on Use of Antibiotics}

Data on veterinary sales of antibiotics for animals in Sweden have been compiled and analysed by the SVA since 1980 [129-134]. Earlier data from the human sector made it possible to compare patterns of antibiotic use in animals and humans [135]. Initially, the data were based on sales of antibiotics for animals from wholesalers to pharmacies, but from 2003, they were based on sales from pharmacies to animal owners (prescriptions) or to veterinarians (requisitions). Specific data on antibiotic use at the farm level are not available, and the identification of sales to specific animal species is limited but can be obtained by combining sales data and data from other sources, as outlined by Grundin et al. [136].

As of 2000, sales data have been reported and analysed by the SVA in the yearly reports from the resistance monitoring programme Svarm (see below). Since 2002, they have been released together with the corresponding data from the human sector (www.sva.se). In addition, sales data have been reported annually to the European monitoring system on antibiotic sales for animals since the start of the programme [10] and to the OIE since 2016 (OIE [137]).

Sales information is regularly communicated at conferences and meetings and also attracts general public interest. It is also used in the formulation of national guidelines on the use of antibiotics and in assessments of compliance with recommendations and regulations on the use and prescription of antibiotics.

\subsection{Access to Data on Antibiotic Resistance}

Data on AMR in animal bacteria have been compiled and presented since the 1950s. Initially, the data originated from prevalence studies and research projects (e.g., [85,86,88,90,138-141]. However, since 1978, resistance in Salmonella spp. from animals has been monitored yearly at the SVA and in 2000, this activity was extended to the Svarm programme, following a government decision. In Svarm, resistance in salmonella, campylobacter, indicator bacteria from healthy animals and several animal pathogens is monitored, and the data are presented and analysed in yearly reports. Since 2012, data from Svarm have been presented with corresponding data from the human sector compiled by the Public Health Agency of Sweden in an integrated report (Swedres-Svarm) available online (www.sva.se).

Data on AMR from a clinical perspective are also regularly communicated to veterinarians at conferences and meetings, in general, highlighting the risks of the misuse and overuse of antibiotics. The data are also used in the elaboration of national guidelines on the use of antibiotics and for evaluating the effects of measures to mitigate resistance, for example, containing the spread of E. coli resistant to ESC in broiler production [57].

\subsection{Policies, Guidelines, Recommendations and Legislation}

Following the ban on AGPs, in 1990, the SVF issued guidelines on the use of antibiotics for the group treatment of pigs [142], and in 1999, it issued a general policy on the use of antibiotics in animals [143]. A policy on the treatment of mastitis in dairy cows was launched by independent experts in 1995 [121]. Later, the SVF gathered practitioners and experts on specific animal species and experts in the field of antibiotics to produce specific guidelines for companion animals, cattle, pigs, horses, sheep and goats. Those documents aim to balance the need for effective therapy with the need to minimise the emergence of AMR, for example, by advocating the use of narrow-spectrum antibiotics and avoidance of substances such as fluoroquinolones and third-generation cephalosporins, which are among the antibiotics of the highest priority of those categorised by the WHO as critically important in human healthcare [144]. The SVF guidelines are revised regularly and available on the website of the organisation (www.svf.se). To complement those policies and guidelines, since 201,2 the Swedish Medical Products Agency has issued 
detailed recommendations on the treatment of specific diseases in various animal species, which are available on the website of the agency (www.lakemedelsverket.se).

Basic elements in the legislation since the 1950s on medicinal products for animals are that antibiotics may only be used in animals after prescription and that veterinarians may not sell antibiotics for profit [145]. Antibiotics may be prescribed to farm personnel for specified clinical conditions in farm animals without the prior examination of an animal by a veterinarian. This so-called "conditional use" is strictly regulated in legislation [146] and includes training courses for farmers and regular visits by the prescribing veterinarian. Since 2014, antibiotics of special importance in human healthcare, for example, glycopeptides, carbapenems and ceftaroline, are restricted from use in animals [146]. The use of fluoroquinolones and third-generation cephalosporins is limited by legislation to situations where laboratory tests show a lack of alternatives. To prevent the spread of contagious diseases at clinics and ambulatory practices, the legislation requires veterinary practitioners to have infection prevention and control plans [126]. These plans must also aim to mitigate the spread of resistant bacteria, for example, methicillin-resistant Staphylococcus pseudintermedius (MRSP), in animal healthcare.

\subsection{Summary of Key Factors}

Since the mid-1950s, shortly after antibiotics became available for use in animals in Sweden, prudent use and the risks of AMR developing have frequently been discussed within the veterinary profession (practitioners and researchers). Antibiotics are considered important tools for the treatment of bacterial infections that need to be protected, not miracle drugs for dramatically improving animal production.

Data on the occurrence of AMR have been collected and disseminated in Sweden since an early stage and show the magnitude of the present and future risks for the veterinary and human sectors. Data on antibiotic sales, regularly reported since 1980, make it possible to assess compliance with legislation and policies. Access to data on AMR and on sales of antibiotics make it possible to devise policies, recommendations, guidelines and legislation, and also to evaluate the effect of actions taken. This has transformed general awareness of AMR into concrete knowledge on prudent use and into concrete actions to mitigate the emergence and spread of AMR.

The ban on AGPs in 1986 decreased the sales of antibiotics substantially and put the focus on disease prevention by other means, including measures for improved animal management, feeding and housing. The discussions leading to the ban involved different actors, including farmers' cooperatives, veterinarians, politicians and relevant authorities, with consumer confidence as an important argument. This made AMR, the use of antibiotics and sustainable animal production important issues on the political agenda, which is still the case [147].

\section{Cooperation in Problem Solving}

\subsection{Control of Infectious Diseases}

In the control of infectious diseases, there is generally constructive cooperation between authorities, industry and academia/veterinary expertise in Sweden. The major stakeholders are the government; the competent authorities; veterinary and other academics; industry, representing farmers, slaughterhouses and dairies; and also animal breeding and animal feed companies. The Federation of Swedish Farmers acts as a link between the government and industry. Examples of formal cooperation are the steering committees for the organised health controls, which cooperate with national authorities and industry. However, "ad hoc groups" have also been formed for other animal health, food safety and public health issues, such as Campylobacter, Salmonella and enterohemorrhagic Escherichia coli (EHEC), and for managing the use of zinc oxide in pig production. A large programme introduced in 2016, with funding from the Swedish Board of Agriculture, focuses on biosecurity on individual holdings, aiming at reducing the spread of 
infectious diseases [148]. The programme is run by the industry-owned animal health service providers.

For the control of endemic diseases, including associated interventions on individual animal holdings, the industry-led veterinary organisations, and experts from academia and from the SVA are the most significant players. Clinical practitioners also play an important role and, together with farmers, are the first to observe and highlight animal health problems, including those related to AMR. Major animal health-related control measures are initially devised by academia, the SVA or industry, and formally elaborated and developed further at meetings chaired by the competent authority.

A One Health perspective has been used to address zoonotic infectious diseases since the Zoonosis Council, including representatives from the human sector, was established as a national collaborative forum for authorities and organisations in 1997 [149]. At council meetings, strategies in the zoonosis area are elaborated and discussed, to achieve mutual understanding between all the authorities and organisations involved.

\subsection{Counteracting $A M R$}

There is also cooperation between stakeholders on specifically addressing AMR, in a way similar to that described for infectious diseases above. For example, since 2005, the SVA and Farm and Animal Health, the industry-owned animal health services provider, have cooperated on monitoring AMR in food animals within the SvarmPat project [128]. Likewise, the SVA cooperates with the SPMA on issues related to AMR in broiler production, for example, on reducing the occurrence of ESBL [128]. Moreover, recommendations and guidelines on the use of antibiotics and measures to mitigate the spread of AMR are elaborated with the participation of experts from several sectors (see above). In 2008, the network Strama VL was started as a platform for enabling stakeholders in the veterinary sector to exchange information, analyse problems, pinpoint solutions and initiate prioritised activities. A secretariat at the SVA coordinates the network and acts as a contact point and a centre of knowledge [150].

A One Health perspective on AMR has been successively introduced by increased cooperation between the veterinary and human sectors. Thus, when the Swedish strategic programme against antibiotic resistance (Strama) was formed in 1995 to counteract AMR in the human sector, the veterinary sector was involved in the network [151]. The cooperation against AMR between sectors was eventually formalised in 2012 by the creation of the Intersectoral Coordinating Mechanism (ICM) chaired by the Public Health Agency of Sweden and the Swedish Board of Agriculture [152]. The ICM brings together representatives from about 20 national authorities and organisations across many sectors: human and animal health, food production, the environment, research, trade and international relations. In the early 2000s, the National Board of Health and Welfare, in cooperation with stakeholders from several sectors, elaborated a proposal for a national strategy on AMR, which was presented to the Swedish Parliament in 2005 [153]. Moreover, under the auspices of the ICM, action plans on AMR for authorities were presented in 2015 [154] and revised in 2017 [155]. Other examples of cooperation are the presentation and analysis of data on antibiotic sales and AMR by the National Veterinary Institute and the Public Health Agency of Sweden in yearly Swedres-Svarm reports (see above) and various research activities, for example, the IMPACT project [156].

\subsection{Agricultural Policy with Incentives for Livestock Production}

Until the early 1990s, Swedish agricultural policy included incentives for livestock production. Apart from broiler production and some minor sectors, domestic food production was supported by a differentiated system of price regulation and other budget measures. This facilitated government support of the animal health sector until Sweden's accession to the EU in 1995. Before then, the Federation of Swedish Farmers held regular formal meetings and negotiations with the government, which included discussions on investments in the animal health sector. This pattern of cooperation has been maintained, 
although economic accountability has been modified, and economic support from the government has generally decreased substantially in recent years.

The costs for the control and eradication of the major epizootic diseases (Table 1) have, to date, been covered by the Swedish government. In the case of salmonella, farmers' costs for eradication were fully covered until 1984, when the compensation was reduced for cattle and pig farms and withdrawn for broiler production [20]. Today, compensation is higher for herds affiliated with organised health controls focusing on biosecurity.

Government support facilitated the creation of the industry-led health counselling veterinary organisations for the prevention of endemic infection. In 1969, the industry became financially responsible for that activity, but up to Sweden's EU accession in 1995, the government continued to provide financial support for the control and eradication of specific diseases through organised health controls (see above, Table 2). That financial support was used to create economic incentives for producers to join control programmes. In addition, animal health insurance companies require farms to have disease prevention measures in place, for example, an affiliation with an organised health control, to qualify for compensation for outbreaks of a disease. Today, the financial support from government is mainly limited to funding the control organisations to perform specific activities considered of national importance, for example, disease surveillance. In addition, since 1934, the government has provided financial support to the district veterinary organisations to ensure that clinical animal health services are available to farmers in the whole of Sweden [20].

\subsection{Summary of Key Factors}

Using regulatory and financial tools, the competent authority in Sweden has facilitated active control solutions for infectious diseases and AMR.

Cooperation between relevant stakeholders has enabled mutual understanding of and consensus on the need for and benefits of implementing measures to prevent and control infectious diseases and to counteract AMR.

Cooperation between national authorities in the human and animal sectors from a One Health perspective has strengthened the basis for strategies against zoonotic diseases and AMR in the animal sector. Research cooperation between the two sectors has further increased consensus.

\section{Discussion}

In Sweden, sales of antibiotics for use in animals and the prevalence of AMR in food animals are low in comparison with those in other EU Member States [11,12]. Moreover, in 2019, more than $90 \%$ of the overall sales of antibiotics for use in animals consisted of products for the treatment of individual animals, $58 \%$ of which were narrow-spectrum benzylpenicillin [128]. These data indicate a limited need for antibiotic therapy and adherence to the principles of prudent use set out by the European Medicines Agency (EMA) [157]. This case study shows that the favourable situation in Sweden is the result of several factors.

\subsection{Early Awareness}

A factor of basic importance is probably the early and now-widespread awareness among veterinarians and farmers of the risks of AMR and the need for the prudent use of antibiotics. This is likely due to the discussions on antibiotic use in animals starting early in Sweden, in the 1950s. These discussions were supported by access to data on antibiotic use after 1980 and early detailed national reports on the occurrence of AMR in bacteria from animals. The Swedish ban on AGPs in 1986, the first in the world, was actually requested by farmers, which exemplifies the general awareness of AMR even at that time. The request for a ban was probably also a response to the ongoing public debate on the state of animal husbandry that started in the mid-1970s and threatened to undermine consumer trust in Swedish food animal production $[114,115]$. 


\subsection{Cooperation in Prevention and Control of Infectious Diseases}

A major reason for the low current use of antibiotics is that the need for antibiotic therapy has been reduced by successful long-term efforts to prevent and control infectious diseases and to eradicate these diseases when possible. These efforts started in the preantibiotic era and demonstrate a committed attitude to the prevention of infectious diseases. In outbreak situations, substantial efforts are made to trace and eliminate the source of infection, making it possible for Sweden to achieve disease-free status even for diseases such as bovine paratuberculosis $[21,158]$ and effectively control and eliminate Salmonella from infected herds and feed mills [21]. An even more important factor in reducing the need for antibiotics is that similar strategies are applied for endemic diseases, applying a concept of "prevention is better than cure", as discussed below.

A significant factor for the achievements in animal health in Sweden is the longstanding cooperation between relevant stakeholders. This enables mutual understanding of and consensus on the need for and benefits of controlling diseases, even among stakeholders with different economic priorities, usually at meetings with a national perspective chaired by the competent authority with its regulatory and economic power, including both a "carrot and stick". For example, active participation by farmers' organisations has been identified as a strong factor in the control of bovine viral diarrhoea (BVDV) [159]. Consensus was reached as early as the 1950s on regulations treating animal feed as a potential source of infection, i.e., a "feed to fork" perspective, in contrast to the "farm to fork" perspective still applied in the EU [160]. Measures to mitigate AMR have been decided in line with the so-called "Swedish model", also accounting for consumer opinion $[16,136]$. Cooperation and consensus between stakeholders has also been identified as a key factor in the success of work against AMR in Danish pig production [161].

\subsection{Organised Health Controls for Prevention of Endemic Diseases}

The introduction of organised health controls in 1969 was strategically important, because it opened the door for indirect government leadership in the control of endemic diseases, in cooperation with industry and its veterinary organisations. In other countries, government and regulatory influence in the prevention and control of endemic diseases is often lacking, although these diseases cause the highest burden in animal production and are the major targets for antibiotic treatments [162]. Furthermore, Sweden considers the control and eradication of viral diseases, which predispose for bacterial infections that require antibiotic treatment (e.g., BVDV, EBL, MV, PRRS, AD, Caprine arthritis encephalitis and infectious bursal disease) to have health-supporting effects beyond their direct clinical impact $[117,163]$. In addition to the eradication of several infections (Table 2), the organised health controls cooperate in the surveillance of infectious diseases and were, for example, early in identifying the introduction of PRRS in 2007, allowing it to be successfully eradicated $[164,165]$. In cases of health problems on individual farms, the ambition is to identify and eliminate the basic problem, i.e., "problem solving at the root", instead of alleviating clinical problems by using antibiotics.

The long-term disease preventive measures taken in collaboration between government agencies and other stakeholders have improved animal health and decreased the need for the use of antibiotics. The best example of this is probably Swedish commercial broilers, with a yearly production of about 100 million chickens, where only $0.25 \%$ of flocks (8 of 3178) were treated with antibiotics in 2018 [166].

\subsection{Financial Incentives}

The national incentives for livestock producers, initially introduced in Sweden to ensure national food security in the event of war and to facilitate the structural rationalisation of the farm industry, limited the cost to individual farmers of joining disease control programmes until Sweden's entry into the EU in 1995. In addition, the price regulation system during that period and limited imports of animal-derived food products minimised the risk of producers losing market share due to the costs of disease control. This facilitated the 
implementation of costly eradication programmes, which were funded on a national basis owing to strong arguments, primarily from veterinarians and industry. This situation may reflect a Swedish attitude to respecting facts and trust among farmers in politicians and relevant animal health authorities, including the industry's own veterinary organisations. Although the control and eradication of diseases in farm animals may seem to be associated with high costs, the actual burden of disease justifies the costs of measures for disease control and hygiene [167]. This is exemplified by the eradication of AD in pigs [168], BVDV in cattle [169] and swine dysentery in pigs [170]. Additionally, when avoided costs for human illness are considered, it has been shown that for salmonella, the benefits exceed the costs for the control [171,172].

\subsection{Access to Data on Sales of Antibiotics and AMR}

Data on sales of antibiotics and the occurrence of AMR have made the discussion on the use of antibiotics more concrete but have also formed the basis for measures and actions and for the evaluation of actions taken. Recommendations and policies on the therapeutic use of antibiotics and infection control procedures have been regularly updated, and actions against resistance of specific importance, for example, MRSA, have been developed, including legislative measures. Policies and guidelines are generally well received and valued by Swedish veterinary practitioners [173,174] and also by Swedish farmers [175]. This approach to interventions against AMR in the face of unwanted trends and new knowledge was highlighted by the Directorate-General for Health and Food Safety (DGSANTE) of the European Commission as an important factor for the favourable situation in Sweden [176], and is in line with the action plans against AMR issued by the WHO [1] and the European Commission [13].

\subsection{Early Action}

It is interesting to note that in three areas of major importance for counteracting AMR, Sweden took control actions long before other countries [136]. The control and eradication of several diseases, for example, Salmonella infections, bTB and brucellosis, was initiated early. The successful control of Salmonella has been recognised internationally; for example, in 1993, Sweden was engaged by the WHO to teach others about Salmonella control in poultry [177]. In 1980, Sweden became the first country in the world to publish data on the sales of antibiotics [133], and in 1986, it became the first country to ban the use of AGPs [114]. The experiences gained in Sweden were valuable when a ban on AGPs was introduced later in other countries, for example, the other Nordic countries $[178,179]$. Sweden was also comparatively early in setting up a comprehensive national monitoring programme for AMR in animals (2000). Furthermore, Sweden was the first country in the world (1986) to ban the use of meat and bone meal from fallen stock or sick animals in animal feed, which apparently protected Sweden from an outbreak of C-type Bovine spongiform encephalopathy BSE [180,181].

\subsection{Geographical Location}

This review did not find any evidence that the geographical location of Sweden or differences in, for example, climate or the intensity and productivity of food animal production could explain the favourable animal health situation and, thereby, the low use of antibiotics. The climate in the regions of Sweden where most food animal production is located is similar to that in northern continental Europe, and the spread of vector-borne diseases to new regions attributed to global warming, for example, bluetongue [182] and Schmallenberg virus [183], has also affected Sweden. Sweden, like several other EU Member States, has a long sea border, which decreases the risk of the uncontrolled transboundary movement of animals and animal products. However, in most countries, outbreaks of transboundary diseases in the past were mainly caused by the regular trade and imports of live animals, before these were properly regulated [184]. We found no indications that the conditions for the dissemination of infectious diseases are different 
in Sweden than in other developed countries. Before effective controls were in place, transboundary diseases introduced into Sweden (Table 1) were spread widely, often up to the far north of the country above the polar circle.

Food animal production in Sweden has, in principle, undergone the same structural changes as in most other developed countries. The spread of infections between and within farms is mainly limited by the biosecurity measures applied on individual farms, which may be more difficult to achieve in countries with denser animal populations than Sweden. However, the size of the national food animal production sector does not appear to be a factor explaining the favourable situation regarding AMR in Sweden [136,161]. For example, the consequences of the withdrawal of AGPs in Danish pig production were very similar to those observed in Sweden 20 years earlier, despite the much larger pig production sector in Denmark $[116,185]$. Since the productivity in Swedish animal food production is generally on the same level as in other developed countries, it can be concluded that it is possible to combine high productivity in animal production with a restricted use of antibiotics, as also found, for example, in Denmark [161]. The experiences from Sweden are, therefore, generally applicable to other countries.

\subsection{Future Challenges}

A major future challenge for Sweden is to find ways to maintain the good status achieved for animal health and AMR while not contravening harmonised EU rules on the intracommunity movement of animals and international standards on trade in live animals. For example, it is of vital importance for Swedish pig production to prevent the introduction of PRRS, which, apart from causing economic losses, would be a major trigger for the increased use of antimicrobials, as found in other countries [163]. In order to comply with the WHO [1] and EU [13], in action plans against AMR, it is therefore necessary for Sweden to find transparent and evidence-based procedures for preventing the introduction or reintroduction of important infections and bacterial strains with special antimicrobial resistance. The new EU Animal Health Law [186] and Veterinary Medicines Regulation [187] provide significant incentives for individual countries and farmers to maintain or improve their animal health status, thereby decreasing the need for antimicrobials, and to strive for a decreased and prudent use of antimicrobials, thereby lowering the risk of the emergence of AMR. These are all necessary steps for EU-wide and global progress in efforts to contain AMR. Another challenge for Swedish pig production is to cope with the phasing out of zinc oxide in the EU [188] without increasing antibiotic use. The ongoing trend towards larger pig and dairy herds might also facilitate the spread of infectious diseases and thereby pose a challenge for infection control. An overall challenge for Swedish producers is to maintain ambition and economic power for animal health investments, which from a short-term perspective, may not be rewarded on the open market. It is crucial to maintain understanding/conviction regarding the overall benefits of healthy animals.

\section{Materials and Methods}

We retrieved and analysed documents published from Sweden since the early 1900s with the aim of identifying factors and measures undertaken that are likely to have contributed to the favourable situation regarding antibiotic use and AMR. The work was structured around the three major areas: 1 . the prevention and control of infectious diseases; 2. antibiotic use and resistance; 3 . cooperation in problem solving. The focus was on farm animals, and as a background, data on the food animal production during the same period were retrieved.

To retrieve scientific documents, we used PubMed searches, and to retrieve grey literature and legislative documents, Google searches were used. In addition, all issues of the journal of the Swedish Veterinary Association since 1945 and the programmes of the yearly national veterinary conferences since the mid-1950s were scrutinized for articles and other material related to antibiotics. Official inquirers related to the animal sector and policy documents on the use of antibiotics were also consulted. In addition, we received 
valuable information and advice from specific key persons (see Acknowledgements) with insight into the animal health sector and the work against AMR in Sweden. These key persons also read and commented on the first draft of this manuscript.

\section{Conclusions}

This case study revealed that a fundamental factor in Sweden's favourable status as regards antibiotic sales and AMR was an early insight into and sustained awareness of the risks of AMR and the need for prudent use to maintain the efficacy of antibiotics. Early access to annual data on antibiotic sales and AMR provided insights and made it possible to focus measures on areas of concern and to assess the impact of these measures.

Another major factor has been the long-term control and eradication of infectious diseases, including endemic diseases, which reduced the need for the use of antibiotics. The structures and strategies established for that purpose, under government leadership and support, also proved useful for counteracting AMR as an integral part of disease prevention and control.

A third vital factor for success has been the consensus among relevant stakeholders on the need to address AMR and control infectious diseases, and stakeholder cooperation in the design and implementation of relevant measures.

In summary, early awareness, longstanding efforts to prevent diseases and consensus between stakeholders explain the success of Swedish work in preventing the development of AMR.

Author Contributions: All authors contributed equally to all aspects of the elaboration of this paper. All authors have read and agreed to the published version of the manuscript.

Funding: This research received no external funding.

Acknowledgments: We gratefully acknowledge the constructive criticism and suggestions for the improvement of this paper received from the following key persons from relevant stakeholders: Jonas Carlsson, Folke Cerenius, Torkel Ekman, Carl Johan Ehlorsson, Anders Franklin, Jenny Frössling, Christina Greko, Lena Hellqvist Björnerot, Håkan Henriksson, Pernilla Ivarsson, Johan Lindblad, Lars Erik Lundkvist, Bengt Nordblom, Kristina Nordéus, My Sahlman, Susanna Sternberg Lewerin, Gunnela Ståhle, Per Wallgren and Ivar Vågsholm.

Conflicts of Interest: The authors declare no conflict of interest.

\section{References}

1. WHO. Global Action Plan on Antimicrobial Resistance. Geneva: World Health Organization. 2015. Available online: http: //www.who.int/antimicrobial-resistance/publications/global-action-plan/en/ (accessed on 26 November 2017).

2. WHO; FAO; OIE. WHO, FAO and OIE Unite in the Fight Against Antimicrobial Resistance. 2015. Available online: www.who. int/foodsafety/areas_work/antimicrobial-resistance/amr_tripartite_flyer.pdf?ua=1 (accessed on 26 November 2017).

3. Swann Committee. Report of the Joint Committee on the Use of Antibiotics in Animal Husbandry and Veterinary Medicine; Her Majesty's Stationery Office: London, UK, 1969.

4. WHO. Guidelines for Surveillance and Control of Antimicrobial Resistance; World Health Organization: Geneva, Switzerland, 1990. Available online: http:/ /apps.who.int/iris/handle/10665/62190 (accessed on 26 November 2017).

5. WHO. The Medical Impact of the Use of Antimicrobials in Food Animals: Report of a WHO Meeting, Berlin, Germany, 13-17 October 1997; World Health Organization: Geneva, Switzerland, 1997. Available online: https://apps.who.int/iris/handle/10665/64439 (accessed on 26 November 2017).

6. WHO. Consultation on Global Principles for the Containment of Antimicrobial Resistance in Animals Intended for Food with the Participation of the Food and Agriculture Organization of the United Nations and the Office International des Epizooties, Geneva, Switzerland 5-9 June 2000; World Health Organization: Geneva, Switzerland, 2000. Available online: http://www.who.int/zoonoses/resources/ amresistance/en/ (accessed on 19 December 2017).

7. WHO. Consultation on Monitoring Antimicrobial Usage in Food Animals for the Protection of Human Health Oslo, Norway, 10-13 September 2001; World Health Organization: Geneva, Switzerland, 2002. Available online: http://www.who.int/zoonoses/ resources/amresistance/en/ (accessed on 19 December 2017).

8. EU. Regulation (Ec) No 1831/2003 of the European Parliament and of the Council of 22 September 2003 on Additives for Use in Animal Nutrition, European Union. 2003. Available online: https:/ / eur-lex.europa.eu/legal-content/EN/TXT/?uri=CELEX\% 3A32003R1831 (accessed on 30 November 2017). 
9. EU. Directive 2003/99/EC of the European Parliament and of the Council of 17 November 2003 on the Monitoring of Zoonoses and Zoonotic Agents, Amending Council Decision 90/424/EEC and Repealing Council Directive 92/117/EEC. European Union, 2003. Available online: https:/ / eur-lex.europa.eu/legal-content/EN/TXT/?uri=CELEX:32003L0099 (accessed on 30 November 2017).

10. EMA. Sales of Veterinary Antimicrobial Agents in 19 EU/EEA Countries in 2010. (EMA/88728/2012); European Medicines Agency: London, UK, 2012. Available online: https://www.ema.europa.eu/en/documents/report/sales-veterinary-antimicrobial-agents19-european-union/european-economic-area-countries-2010-second-european-surveillance-veterinary-antimicrobial_en.pdf (accessed on 2 February 2020).

11. EMA. European Surveillance of Veterinary Antimicrobial Consumption, 2020. 'Sales of Veterinary Antimicrobial Agents in 31 European Countries in 2018'. (EMA/24309/2020); European Medicines Agency: London, UK, 2020. Available online: https:/ / www.ema.europa.eu/en/documents/report/sales-veterinary-antimicrobial-agents-31-european-countries-2018 -trends-2010-2018-tenth-esvac-report_en.pdf (accessed on 15 August 2020).

12. EFSA; ECDC. The European Union Summary Report on Antimicrobial Resistance in zoonotic and indicator bacteria from humans, animals and food in 2017/2018. EFSA J. 2020, 18, e06007. [CrossRef]

13. European Commission. The New EU One Health Action Plan against Antimicrobial Resistance. Available online: https: / / ec.europa.eu/health/amr/action_eu_en. (accessed on 15 August 2020).

14. SBA. Jordbruksverkets Statistkdatabas: Swedish Board of Agriculture. 2019. Available online: http://statistik.sjv.se/PXWeb/ pxweb/sv/Jordbruksverkets\%20statistikdatabas (accessed on 18 December 2019).

15. SBA. Mjölkkor, Mjölkproduktion Och Mjölkföretag: Utvecklingen de Senaste 40 Åren 1979-2019; Swedish Board of Agriculture: Jönköping, Sweden, 2020. Available online: https:/ /jordbruketisiffror.wordpress.com/2020/02/03/mjolkkor-mjolkproduktionoch-mjolkforetag-utvecklingen-de-senaste-40-aren-1979-2019/ (accessed on 20 November 2020).

16. FAO. Tackling Antimicrobial Use and Resistance in Dairy Cattle. Lessons Learned in Sweden; Food and Agricultural Organization of the United Nations; Swedish University of Agricultural Sciences: Rome, Italy, 2020. [CrossRef]

17. Farm and Animal Health. Medeltal Slaktgrisar 2020. Available online: https://www.gardochdjurhalsan.se/winpig/medeltaloch-topplistor/medeltal-slaktgrisar/ (accessed on 20 November 2020).

18. SBA. Jordbruket i Siffror Åren 1866-2007; Swedish Board of Agriculture: Jönköping, Sweden, 2020. Available online: https: //webbutiken.jordbruksverket.se/sv/artiklar/jordbruket-i-siffror.html (accessed on 20 November 2020).

19. Lannhard-Öberg, Å. Marknadsrapport Matfågel-Utveckling Till Och Med 2018; Swedish Board of Agriculture: Jönköping, Sweden, 2019. Available online: https:/ / djur.jordbruksverket.se/download/18.627722c3162be21b148cb83b/1556113402295/ Marknadsrapport\%20matf\%C3\%A5gel\%202019.pdf (accessed on 16 October 2019).

20. Cerenius, F. The History of the Swedish Control of Animal End Zoonotic Diseases (In Swedish; Det svenska smittskyddets historia fram till 2000). In Folkhälsa-Djurhälsa; Ny Ansvarsfördelning Mellan Stat Och Näring; Del C SOU 2010:106; Government Offices of Sweden: Stockholm, Sweden, 2010; ISBN 978-91-38-23520-1. Available online: https: / / issuu.com/patriciadunphy / docs/9789174371215_2 (accessed on 12 October 2017).

21. SVA. Surveillance of Infectious Diseases in Animals and Humans in Sweden 2019 Uppsala, Sweden: National Veterinary Institute. 2020. Available online: https://www.sva.se/media/fpodqpau/surveillance_2019.pdf (accessed on 15 August 2020).

22. OIE. World Animal Health Information Database; World Organisation for Animal Health: Paris, France, 2021. Available online: https:/ / www.oie.int/wahis_2/public/wahid.php/Wahidhome/Home (accessed on 10 December 2020).

23. Jerlow, S.; Jerlow, S. Nötkreatursstuberkulosen i Sverige dess utbredning och bekämpande. Historik utarbetad på uppdrag av Sveriges Veterinärförbund; Sveriges Veterinärförbund: Norrtälje, Sweden, 1957; 48p.

24. Björkman, G.; Bengtsson, H. Eradication of bovine brucellosis in Sweden. J. Am. Vet. Med. Assoc. 1962, 140, 1192-1195. [PubMed]

25. Lagerlöf, N. Bekämpandet av Smittsamma Husdjurssjukdomar; Kungliga Skogs-och Lantbruksakedemien: Stockholm, Sweden, 1962.

26. Lundbeck, H.; Plazikowski, U.; Silverstolpe, L. The Swedish Salmonella outbreak of 1953. J. Appl. Bacteriol. 1955, 18, 535-548. [CrossRef]

27. Silverstolpe, L.; Wranne, N. Salmonella outbreaks in Sweden in the county of Ostergotland in 1953. Nord. Hyg. Tidskr. 1955, 36, 213-229. [PubMed]

28. Kunglig Majestät. Kungl. Maj:ts Förordning om Bekämpande av Salmonellainfektioner Hos Djur: 1961:309; Kunglig Majestät: Stockholm, Sweden, 1961.

29. SVA. Salmonella Control/Surveillance; National Veterinary Institute: Uppsala, Sweden, 2020. Available online: https://www.sva. se/en/our-topics/feed-safety/salmonella-control-surveillance/ (accessed on 17 July 2020).

30. Veterinärstyrelsen. Veterinärstyrelsens Kungörelse Om Frivillig Salmonellakontroll av Fjäderfäbesättningar, VF 1970:57; Veterinärstyrelsen: Stockholm, Sweden, 1970.

31. SFS. Förordning om Bekämpande av Salmonella Hos Djur, SFS 1984:306, Swedish Code of Statues. $1984 . \quad$ Available online: https://www.riksdagen.se/sv/dokument-lagar/dokument/svensk-forfattningssamling/forordning-1984306-ombekampande-av-salmonella_sfs-1984-306 (accessed on 17 July 2020).

32. Wierup, M.; Engstrom, B.; Engvall, A.; Wahlstrom, H. Control of Salmonella Enteritidis in Sweden. Int. J. Food Microbiol. 1995, 25, 219-226. [CrossRef] [PubMed] 
33. EU. Council Directive 92/117/EEC of 17 December 1992 Concerning Measures for Protection against Specified Zoonoses and Specified Zoonotic Agents in Animals and Products of Animal Origin in Order to Prevent Outbreaks of Food-Borne Infections and Intoxications; European Union: Brussels, Belgium, 1992. Available online: https:/ / eur-lex.europa.eu/legal-content/EN/TXT/?uri=CELEX\% 3A31992L0117 (accessed on 18 July 2020).

34. Rutqvist, L.; Swahn, O. Epizootologiska och bakteriologiska undersökningar vid mjältbrandsepizootien i Sverige $1956-1957$. Nord. Vet. Med. 1957, 9, 641-663.

35. SJVFS. Statens Jordbruksverks Föreskrifter Om Foder, SJVFS 1993:177; Swedish Board of Agriculture: Jönköping, Sweden, 1992.

36. SJVFS. Statens Jordbruksverks Föreskrifter Och Allmänna Råd Om Foder, SJVFS 2018:33; Swedish Board of Agriculture: Jönköping, Sweden, 2018. Available online: https:/ /lagen.nu/sjvfs/2018:33 (accessed on 17 July 2020).

37. Wierup, M. Production of Soy Bean Derived Feed Material Free from Salmonella Contamination-an Essential Food Safety Challenge. 2017. Available online: https:/ / www.intechopen.com/books/soybean-the-basis-of-yield-biomass-and-productivity / productionof-soybean-derived-feed-material-free-from-salmonella-contamination-an-essential-food-saf (accessed on 18 July 2020).

38. SFS. Livsmedelslag, SFS 1971:511, Swedish Code of Statues. 1971. Available online: https://www.riksdagen.se/sv/dokumentlagar/dokument/svensk-forfattningssamling/livsmedelslag-1971511_sfs-1971-511 (accessed on 17 July 2020).

39. Wierup, M. Our Aim: Sound and Competitive Production of Healthy Animals; The Swedish Animal Health Service: Stockholm, Sweden, 1994. Available online: https://www.gardochdjurhalsan.se/wp-content/uploads/2020/06/the_swedish_animal_ health_service_mw_1994.pdf (accessed on 6 April 2019).

40. Government Offices of Sweden. Veterinärväsendeutredningen. Veterinärmedicinsk rådgivnings- och laboratorieverksamhet; Ds Jo 1968:3; Government Offices of Sweden: Stockholm, Sweden, 1968.

41. SJVFS. Statens Jordbruksverks Föreskrifter Om Frivillig Organiserad Hälsokontroll Av Husdjur, SJVFS 2015:17; Swedish Board of Agriculture: Jönköping, Sweden, 2015. Available online: https:/ /lagen.nu/sjvfs/2015:17 (accessed on 17 July 2020).

42. Holmström, A.; Robertsson, J.-Å.; Elvander, M.; Engvall, A.; Larsson, B. Health control in Swedish pig production-A joint effort between the state and the farmers. In Proceedings of the 16th IPVS Congress, Melbourne, Australia, 17-20 September 2000; p. 151.

43. Björnerot, L.; Lindqvist, H.; Stenebo, H.; Treiberg-Berndtsson, L. (Eds.) The Eradication Programme Against BHV-1 in Sweden. In Proceedings of the VIIIth Symposium International d' Epidemiologie et d' Economie Veterinaires, Paris, France, 8-11 July 1997.

44. Jansson, D.S. Virussjukdomar hos fjäderfä (Viral diseases in poultry). In Information från Läkemedelsverket Supplement 30, Behandling och Profylax av Infektioner Hos Fjäderfä-Behandlingsrekommendation; Swedish Medical Products Agency: Uppsala Sweden, 2019. Available online: https:/ / www.lakemedelsverket.se/fjaderfa (accessed on 20 June 2020).

45. Klintevall, K.; Naslund, K.; Svedlund, G.; Hajdu, L.; Linde, N.; Klingeborn, B. Evaluation of an indirect ELISA for the detection of antibodies to bovine leukaemia virus in milk and serum. J. Virol. Methods 1991, 33, 319-333. [CrossRef] [PubMed]

46. McCarthy, C.; Hoglund, J.; Christley, R.; Juremalm, M.; Kozlova, I.; Smith, R.; van Dijk, J. A novel pooled milk test strategy for the herd level diagnosis of Dictyocaulus viviparus. Vet. Parasitol. X. 2019, 1, 100008. [CrossRef]

47. Engel, M.; Wierup, M. Eradication of Aujeszky's disease virus from a Swedish pig herd using gI-/TK-vaccine. Vet Rec. 1997, 140, 493-495. [CrossRef] [PubMed]

48. Jacobsson, M. Antibiotikaterapi vid spädgrisdiarré (Antibiotic therapy in piglet diarrhea). In Information Från Läkemedelsverket Supplement 1, Antibiotika till Gris-Behandlingsrekommendation; Swedish Medical Products Agency: Uppsala, Sweden, 2012. Available online: https:/ / www.lakemedelsverket.se/antibiotikatillgris (accessed on 20 June 2020).

49. Fellström, C.; Pringle, M. Dosering av antibiotika till gris-Brachyspira-infektioner (Dosage of antibiotics in pigs-Brachspira infections). In Information Från Läkemedelsverket Supplement 1, Behandling och Profylax av Infektioner Hos Fjäderfä-Behandlingsrekommendation; Swedish Medical Products Agency: Uppsala, Sweden, 2012. Available online: https://www.lakemedelsverket.se/ antibiotikatillgris (accessed on 20 June 2020).

50. Holmström, A. Redogörelse för Husdjursorganisationernas Djurhälsovård 2018/2019. Växa Sverige, 2019. Available online: https: //www.vxa.se/globalassets/dokument/statistik/redogorelse-for-husdjursorganisationernas-djurhalsovard-2018-2019.pdf (accessed on 20 June 2020).

51. Pedersen, K.; Nilsson, O.; Jansson, D.S.; Berndtson, E. Bakteriella infektioner hos fjäderfä (Bacterial diseases in poultry). In Information Från Läkemedelsverket Supplement 30, Behandling Och Profylax av Infektioner Hos Fjäderfä-Behandlingsrekommendation; Swedish Medical Products Agency: Uppsala, Sweden, 2019. Available online: https://www.lakemedelsverket.se/fjaderfa (accessed on 20 June 2020).

52. SBA. Populärvetenskapliga Sammanfattningar av Projekt Och Övervakning; Swedish Board of Agriculture: Jönköping, Sweden, 2019. Available online: www.jordbruksverket.se/amnesomraden/djur/sjukdomarochsmittskydd/ansokanomanslagsmedel/ redovisningavprojekt.4.71fce1b01544ca768ac87af5.html (accessed on 21 June 2020).

53. SDS. Swedish Farmers Disease Control Program 2020. Available online: http:/ / www.sds-web.se/en/ (accessed on 1 December 2020).

54. Albina, E. Epidemiology of porcine reproductive and respiratory syndrome (PRRS): An overview. Vet. Microbiol. 1997, 55, 309-316. [CrossRef] [PubMed]

55. Unnerstad, H.E.; Wahlstrom, H.; Molander, B.; Bengtsson, B. Methicillin-resistant Staphylococcus aureus not detected in Swedish nucleus and multiplying pig herds. Infect. Ecol. Epidemiol. 2017, 7, 1313068. [CrossRef] [PubMed]

56. Swedres-Svarm 2018. Consumption of Antimicrobials and Occurrence of Antimicrobial Resistance in Sweden; Public Health Agency of Sweden/National Veterinary Institute: Solna/Uppsala, Sweden, 2019; ISSN 1650-6332. Available online: www.strama.se (accessed on 14 June 2019). 
57. Nilsson, O.; Borjesson, S.; Landen, A.; Greko, C.; Bengtsson, B. Decreased detection of ESBL- or pAmpC-producing Escherichia coli in broiler breeders imported into Sweden. Acta Vet. Scand. 2020, 62, 33. [CrossRef] [PubMed]

58. Andreasen, C.B.; Spickler, A.R.; Jones, B.E. Swedish animal welfare regulations and their impact on food animal production. J. Am. Vet. Med. Assoc. 2005, 227, 34-40. [CrossRef] [PubMed]

59. SVA. Poultry: National Veterinary Institute. 2020. Available online: https://www.sva.se/en/animals/poultry/ (accessed on 17 July 2020).

60. SJVFS. Statens Jordbruksverks Föreskrifter Och Allmänna Råd Om Grishållning Inom Lantbruket m.m., SJVFS 2019:20; Swedish Board of Agriculture: Jönköping, Sweden, 2019. Available online: https:/ /lagen.nu/sjvfs/2019:20 (accessed on 19 July 2020).

61. Wallgren, T.; Lundeheim, N.; Wallenbeck, A.; Westin, R.; Gunnarsson, S. Rearing Pigs with Intact Tails-Experiences and Practical Solutions in Sweden. Animals 2019, 9, 812. [CrossRef] [PubMed]

62. Honeyman, M.S. Demonstration of a Swedish Sustainable Swine Production System in Iowa; Iowa State University: Ames, IA, USA, 1998. Available online: http:/ /lib.dr.iastate.edu/leopold_grantreports/116 (accessed on 22 June 2020).

63. EFSA. Opinion of the Scientific Panel on Animal Health and Welfare (AHAW) on a request from the Commission related to welfare of weaners and rearing pigs: Effects of different space allowances and floor. EFSA J. 2005, 3, 268. [CrossRef]

64. EFSA. Opinion of the Scientific Panel on Animal Health and Welfare on a request from the Commission related to animal health and welfare in fattening pigs in relation to housing and husbandry. EFSA J. 2007, 5, 564. [CrossRef]

65. André, T. Nytt på antibiotikafronten. Medl. Sver. Veterinärförbund 1957, 9, 224-232.

66. Ericsson, H. Rationellt bruk av antibiotika. Medl. Sver. Veterinärförbund 1961, 13, 117-124.

67. Holtenius, P. Antibiotikabehandling. Malmöhus Läns Hushållningssällskaps Kvart. 1959, 79, $213-217$.

68. Hydén, S. Antibiotikaanvändningen måste kontrolleras. Överkänslighet och resistens är riskmoment. Jordbr. Föreningsblad 1967, $29,13$.

69. Månsson, I. Antibiotikaterapi-några synpunkter. Medl. Sver. Veterinärförbund 1958, 10, 406.

70. Thörne, H. Penicillin-penicillinas-penicillinasantiserum. Medl. Sver. Veterinärförbund 1960, 12, 414.

71. Dalgaard-Mikkelsen, S. Antibiotika-ett hjälpmedel och ett faromoment. Medlemsblad Sver. Veterinärförbund 1963, 15, 173-174.

72. Ehlers, T. Foderantibiotika. Medlemsblad Sver. Veterinärförbund 1963, 15, 8-13.

73. Funke, H. Foderantibiotika och resistenta bakteriestammar. Sven. Vet. Tidn. 1969, 21, 478.

74. Rutqvist, L. Antibiotikaresistens hos bakterier. Sven. Vet. Tidn. 1970, 22, 307-308.

75. Rutqvist, L.; Swahn, O. Veterinary aspects on the use of antibiotic feed supplements in animal husbandry. Sven. Vet. Tidn. 1968, 20,461-462.

76. Holtenius, P. Övertro på antibiotika. Månadsblad Tidskr. Skand. Kreat. 1964, 37, 31.

77. Hydén, S. Använder vi för mycket antibiotika? Medl. Sver. Veterinärförbund 1958, 10, 424-425.

78. Kolmodin, P.I. Antibiotika. Hallands Läns Hushållningssällskaps Tidskr. 1966, 9, 103-105.

79. Swahn, O. Antibiotika i husdjursfoder. Skånskt Lantbr. 1970, 3, 538.

80. Svensson, T. Antibiotika i fodret-kommentar. Våra Pälsdjur 1966, 36, 445.

81. Lundström, H. Antibiotikadebatten vid årets veterinärmöte. Sven. Vet. Tidn. 1973, 25, 698.

82. Jonsson, G.; Jacobsson, S.-O. Foderantibiotikas inverkan på kalvdödligheten. Sven. Vet. Tidn. 1973, 25, 17-22.

83. Bäck, E.; Niklasson, P.-M. Antibiotika-bruk och missbruk. Sven. Vet. Tidn. 1973, 25, 3-8.

84. Sköld, O. Överkonsumtion av antibiotika-ett medicinskt miljöproblem. Sven. Vet. Tidn. 1973, 25, 9-14.

85. Bäckström, L.; Karlsson, R. Resistenser hos svinpatogena coli. Sven. Vet. Tidn. 1973, 175-184.

86. Franklin, A. Antibiotikakänslighet hos Escherichia coli-stammar isolerade från spädgrisar i Sverige 1964-68 samt 1974-75. Sven. Vet. Tidn. 1976, 28, 845-852.

87. Gustafson, B.; Svehag, S.E. Resistensprövning av stafylokocker isolerade från hund. Nord. Vet. Med. 1956, 8, $493-496$.

88. Karlsson, K.A.; Nyström, K.G. In vitro sensitivity of bovine and procine strains of Pasteurella multocida to antibiotics. Acta Vet. Scand. 1962, 3, 226-234. [CrossRef]

89. Wallmark, G.; Thörne, H. Bacteriophage-types and sensitivity to penicillin of Staphylococci isolated from bovine mastitis. Nord. Vet. Med. 1958, 10, 76-81.

90. Wierup, M. Sensitivity to sulfamethoxazole-trimethoprim of Escherichia coli isolated from calves (in Swedish). Nord. Vet. Med. 1974, 26, 626-633. [PubMed]

91. Franklin, A.; Glatthard, V. R-factor-mediated antibiotic resistance in Escherichia coli strains isolated from piglets in Sweden. Zent. Bakteriol. Orig. A 1977, 238, 208-215.

92. Ullberg, S.; Hansson, E.; Funke, H. Distribution of penicillin in mastitic udders following intramammary injection; An autoradiographic study. Am. J. Vet. Res. 1958, 19, 84-92. [PubMed]

93. Holmberg, O.; Åström, G. Ampicillinkoncentration i mjölk hos ko. Sven. Vet. Tidn. 1978, 30, 147-151.

94. Luthman, J.; Jacobsson, S.-O. Serumkoncentrationer av tetracykliner efter oral och parenteral tillförsel. Sven. Vet. Tidn. 1978, 30, 87-92.

95. Luthman, J.; Jacobsson, S.-O. Serumkoncentrationer av sulfonamider efter oral och parenteral tillförsel. Sven. Vet. Tidn. 1979, 31, 783-787.

96. Luthman, J.; Jacobsson, S.-O. Ampicillintrihydrat till nötkreatur. Sven. Vet. Tidn. 1980, 32, 611-613. 
97. Luthman, J.; Löfstedt, M.; Martinsson, K. Serumkoncentrationer av klortetracyklin hos svin efter utfodring med högdosfoder. Sven. Vet. Tidn. 1979, 31, 709-711.

98. Bäckström, G.; Funke, H. Antibiotikautsöndringen hos kor behandlade med långtidsverkande antibiotika. Sven. Vet. Tidn. 1975, 27, 233-237.

99. Appelgren, L.-E. Antibiotika och kemoterapeutika inom veterinärmedicinen-en orientering om farmakokinetiska grundbegrepp. Sven. Vet. Tidn. 1981, 33, 623-629.

100. Franklin, A. Antibiotikaresistensundersökningar. Sven. Vet. Tidn. 1981, 33, 631-641.

101. Funke, H. Behandling av juverinflammation. Sven. Vet. Tidn. 1981, 33, 647-652.

102. Luthman, J. Serumkoncentrationer av kemoterapeutika hos olika djurslag. Sven. Vet. Tidn. 1981, 33, 635-641.

103. Björklund, N.-E.; Olsson, B.; Sorelius, L. Svensk Vet Tidn. Sven. Vet. Tidn. 1966, 3, 364-367.

104. Bäckström, G. Sintidsbehandling av kroniska Stafylokockmastiter hos ko med långtidsutsöndrande antibiotika. Sven. Vet. Tidn. 1972, 24, 403-410.

105. Bäckström, G.; Larsson, E.; Funke, H. Behandlingsresultat vid kliniska mastiter. Sven. Vet. Tidn. 1976, 28, 187-195.

106. Carlquist, H. Försök med Juvanesta comp. vid juverinflammationer. Sven. Vet. Tidn. 1968, 74-75.

107. Funke, H. Intramuskulär behandling av kliniska mastiter. Sven. Vet. Tidn. 1979, 31, 582-585.

108. Hansson, K.-Å. Behandling av akut mastit-ett jämförande försök. Sven. Vet. Tidn. 1980, 32, $23-25$.

109. Klingborn, B.; Lunsjö, A.; Rabe, J.; Wemmert, L. Försök med tylosin i fodret till smågrisar. Sven. Vet. Tidn. 1974, 78-81.

110. Nilsson, S. Några behandlingsresultat med streptomycin mot diarré hos kalvar och grisar. Medl. Sver. Veterinärförbund 1955, 7, 81-82.

111. Orstadius, K.; Dahlberg, G. Behandling efter bakteriologisk resistensundersökning vid urinvägsinfektioner hos hund. Nord. Vet. Med. 1966, 17, 497-503.

112. Segerström, L. Oral penicillinterapi 2 respektive 3 gånger dagligen. Sven. Vet. Tidn. 1979, 31, 197-200.

113. Thafvelin, B. Klinisk prövning av tylosin vid svindysenteri. Sven. Vet. Tidn. 1968, 5, 109-112.

114. Nordéus, K. The Swedish ban on antibiotic growth promoters-the roles of involved actors. In Leche y Lecheras en el Siglo XX. De la Fusión Innovadora Orgánica a la Revolución Verde, 1st ed.; Prieto, L.F., Táboas, D.L., Eds.; University of Zaragosa: Zaragosa, Spain, 2019; pp. 251-286.

115. Andreasen, C.B.; Spickler, A.R.; Jones, B.E. Swedish antimicrobial regulations and their impact on food animal production. J. Am. Vet. Med. Assoc. 2005, 227, 41-45. [CrossRef]

116. Wierup, M. The Swedish experience of the 1986 year ban of antimicrobial growth promoters, with special reference to animal health, disease prevention, productivity, and usage of antimicrobials. Microb. Drug Resist. 2001, 7, 183-190. [CrossRef]

117. Wierup, M. The control of microbial diseases in animals: Alternatives to the use of antibiotics. Int. J. Antimicrob. Agents 2000, 14, 315-319.

118. Government Offices of Sweden. Antimicrobial Feed Additives. Report from the Commission on Antimicrobial Feed Additives; SOU 1997:132; Ministry of Enterprise and Innovation: Stockholm, Sweden, 1997. Available online: https:/ /www.government.se/legaldocuments / 1997/01/sou-1997132 (accessed on 20 June 2020).

119. European Commission. Opinion of the Scientific Steering Committee on Antimicrobial Resistance; European Commission DirectorateGeneral XXIV on Consumer Policy and Consumer Health Protection: Brussels, Belgium, 1999. Available online: http://strama se/wp-content/uploads/2016/04/SSC-document.pdf (accessed on 3 March 2019).

120. Castanon, J.I. History of the use of antibiotic as growth promoters in European poultry feeds. Poult. Sci. 2007, 86, $2466-2471$. [CrossRef] [PubMed]

121. Ekman, T.; Franklin, A.; Sandgren, C.H.; Jonsson, P. Antibiotikapolicy vid behandling av mastit hos ko-"revisited". Sven. Vet. Tidn. 1995, 47, 665-669.

122. Robertsson, J.A.; Franklin, A. Antibiotic resistance of bacteria isolated from cases of acute mastitis in cows. Sven. Vet. Tidn. 1987, $39,115-120$.

123. Swedres-Svarm 2014. Consumption of Antimicrobials and Occurrence of Antimicrobial Resistance in Sweden; Public Health Agency of Sweden/National Veterinary Institute: Solna/Uppsala, Sweden, 2015; ISSN 1650-6332. Available online: www.strama.se (accessed on 8 April 2019).

124. Swedres-Svarm 2016. Consumption of Antimicrobials and Occurrence of Antimicrobial Resistance in Sweden; Public Health Agency of Sweden/National Veterinary Institute: Solna/Uppsala, Sweden, 2017; ISSN 1650-6332. Available online: www.strama.se (accessed on 8 April 2019).

125. SJVFS. Statens Jordbruksverks Föreskrifter om Anmälningspliktiga Djursjukdomar Och Smittämnen, SJVFS 2012:24; Swedish Board of Agriculture: Jönköping, Sweden, 2012. Available online: https://djur.jordbruksverket.se/download/18.3620351113a04a2bd9b8 000962/1370040546533/2012-024.pdf (accessed on 10 May 2020). 
126. SJVFS. Statens Jordbruksverks Föreskrifter Och Allmänna Råd Om Förebyggande Och Särskilda Åtgärder Avseende Hygien m.m. för att Förhindra Spridning av Zoonoser Och Andra Smittämnen, SJVFS 2013:14; Swedish Board of Agriculture: Jönköping, Sweden, 2013. Available online: https: / / djur.jordbruksverket.se/download/18.2ae27f0513e7888ce22800010291/1370040513684/2013-014.pdf (accessed on 10 May 2020).

127. Swedish Veterinary Association. Sveriges Veterinärmedicinska Sällskaps Riktlinjer för Hantering av Hund- Och Kattpatienter Med Bakterier Med Särskild Resistens. Available online: www.svf.se. (accessed on 10 May 2020).

128. Swedres-Svarm 2019. Consumption of Antimicrobials and Occurrence of Antimicrobial Resistance in Sweden; Public Health Agency of Sweden/National Veterinary Institute: Solna/Uppsala, Sweden, 2020; ISSN 1650-6332. Available online: www.strama.se (accessed on 2 September 2020).

129. Björnerot, L.; Franklin, A.; Tysen, E. Usage of antibacterial and antiparasitic drugs in animals in Sweden between 1988 and 1993. Vet. Rec. 1996, 139, 282-286. [CrossRef] [PubMed]

130. Odensvik, K. Försäljning av antibakteriella och antiparasitära läkemedel för djur-1999 års siffror. Sven. Vet. Tidn. 2000, 52, 445-448.

131. Odensvik, K.; Greko, C. Antibakteriella läkemedel för djur-en uppdatering. Sven. Vet. Tidn. 1998, 50, 313-316.

132. Wierup, M. Antibiotikaförbrukning hos djur i Sverige under perioden 1980-1987. Sven. Vet. Tidn. 1989, 41, $299-311$.

133. Wierup, M.; Lowenhielm, C.; Wold-Troell, M.; Agenas, I. Animal consumption of antibiotics and chemotherapeutic drugs in Sweden during 1980, 1982 and 1984. Vet. Res. Commun. 1987, 11, 397-405. [CrossRef] [PubMed]

134. Odensvik, K. Antibakteriella läkemedel för djur-1998 års siffror. Sven. Vet. Tidn. 1999, 51, 369-371.

135. Wierup, M. Human and animal consumption of antibiotics and chemotherapeutic drugs in Sweden during 1980. In Antimicrobials and Agtriculture 4th International Symposium on Antibiotics in Agriculture: Benefits and Malefits; Woodbine, M., Ed.; Butterworths: London, UK, 1984; pp. 483-489.

136. Grundin, J.; Blanco-Pendeno, I.; Fall, N.; Lewerin, S.S. The Swedish Experience-a Summary on the Swedish Efforts towards a Low and Prudent Use of Antibiotics in Animal Production Uppsala; Swedish University of Agricultural Sciences: Uppsala, Sweden, 2020. Available online: https://www.slu.se/en/Collaborative-Centres-and-Projects/slu-future-animals-nature-and-health/ forskning/publications/rapporter/the-swedish-experience/ (accessed on 3 November 2020).

137. OIE. OIE Annual Report on Antimicrobial Agents Intended for Use in Animals; World Organisation for Animal Health: Paris, France, 2020. Available online: www.oie.int (accessed on 15 November 2020).

138. Franklin, A. Antibiotic sensitivity of udder pathogens. Sven. Vet Tidn. 1988, 40 (Suppl. S17), 21-31.

139. Franklin, A.; af Rantzien, M.H. Antimicrobial drug susceptibility of Staphylococcus aureus strains isolated from bovine milk. Nord. Vet. Med. 1983, 35, 460-464. [PubMed]

140. Månsson, I.; Niléhn, P.-O. Sensitivity of bacteria isolated from veterinary clinical material to various antibiotics. Nord. Vet. Med. 1959, 903-990.

141. Nystrom, G. Sensitivity of Salmonella bacteria in vitro to different antibiotics and chemotherapeutics. Acta Pathol. Microbiol. Scand. 1960, 50, 303-321. [CrossRef] [PubMed]

142. Swedish Veterinary Association. Riktlinjer för antibiotikainblandning i foder till svin. Sven. Vet. Tidn. 1990, 42, 407-413.

143. Swedish Veterinary Association. Sveriges Veterinärförbunds antibiotikapolicy. Sven. Vet. Tidn. 1999, 51, 38-40.

144. WHO. Critically Important Antimicrobials for Human Medicine, 6th ed.; World Health Organization: Geneva, Switzerland, 2019. Available online: https:/ / www.who.int/foodsafety/publications/antimicrobials-sixth/en/ (accessed on 10 May 2020).

145. SJVFS. Föreskrifter Om Ändring i Statens Jordbruksverks Föreskrifter (SJVFS 1995:105) Om Avgifter Vid Veterinär Yrkesutövning; SJVFS 2000:65; Swedish Board of Agriculture: Jönköping, Sweden, 2000. Available online: https:/ / djur.jordbruksverket.se/download/ 18.26424bf71212ecc74b080002036/1370043216645/2000-149.pdf (accessed on 10 May 2020).

146. SJVFS. Statens Jordbruksverks Föreskrifter om Läkemedel Och Läkemedelsanvändning; SJVFS 2019:32; Swedish Board of Agriculture: Jönköping, Sweden, 2019. Available online: https:/ /lagen.nu/sjvfs/2019:32 (accessed on 10 May 2020).

147. Government Offices of Sweden. Swedish Strategy to Combat Antibiotic Resistance 2020-2023. Government Offices of Sweden, 2020. Available online: https://www.government.se/499178/globalassets/government/dokument/socialdepartementet/amr_ strategi_eng_web.pdf (accessed on 10 May 2020).

148. Farm and Animal Health; Växa Sverige. Smittsäkra.se 2020. Available online: http://www.smittsäkra.se/ (accessed on 18 November 2020).

149. Government Offices of Sweden. Folkhälsa-Djurhälsa. Ny Ansvarsfördelning Mellan Stat Och Näring; SOU $2010: 106$ Del B.; Ministry of Enterprise and Innovation: Stockholm, Sweden, 2010. Available online: https:/ /www.regeringen.se/rattsliga-dokument/ statens-offentliga-utredningar/2011/01/sou-2010106/ (accessed on 3 March 2020).

150. SVA. Strama VL; National Veterinary Institute: Uppsala, Sweden, 2020. Available online: https://www.sva.se/djurhalsa/ antibiotika/strama-vl/ (accessed on 15 March 2020).

151. Strama. The Swedish Strategic Programme against Antibiotic Resistance 2020. Available online: https://strama.se (accessed on 15 March 2020).

152. PHAS. Intersectoral Coordinating Mechanism against Antibiotic Resistance Public Health Agency of Sweden. 2020. Available online: https:/ / www.folkhalsomyndigheten.se/the-public-health-agency-of-sweden/communicable-disease-control/antibioticsand-antimicrobial-resistance/intersect-collab-mechanism-against-antibiotic-resistance/ (accessed on 15 March 2020). 
153. Government Offices of Sweden. Prop (2005/06:50) Strategi för ett Samordnat Arbete Mot Antibiotikaresistens Och Vårdrelaterade Infektioner; Ministry of Health and Social Affairs: Stockholm, Sweden, 2005. Available online: https://www.regeringen.se/ rattsliga-dokument/proposition/2005/12/prop.-20050650/ (accessed on 15 March 2020).

154. PHAS; SBA. Handlingsplan Mot Antibiotikaresistens Och Vårdrelaterade Infektioner-Underlag för Myndigheternas Fortsatta Arbete; Public Health Agency of Sweden and Swedish Board of Agriculture: Jönköping, Sweden, 2015. Available online: www. folkhalsomyndigheten.se/publicerat-material/ (accessed on 15 March 2020).

155. PHAS; SBA. Reviderad Tvärsektoriell Handlingsplan Mot Antibiotikaresistens 2018-2020. Underlag för Samverkansgruppens Fortsatta arbete; Public Health Agency of Sweden and Swedish Board of Agriculture: Solna/Jönköping, Sweden, 2017. Available online: www.folkhalsomyndigheten.se/publicerat-material/ (accessed on 15 March 2020).

156. PHAS. IMPACT-A One Health Collaboration on Antibiotic Resistance for Sustainable Change; Public Health Agency of Sweden: Solna, Sweden, 2020. Available online: https:/ / www.folkhalsomyndigheten.se/contentassets /657281f2cfca40d29591767b73c0b3b5 /impact_project_summary.pdf (accessed on 15 March 2020).

157. EMA/AMEG. Categorisation of Antibiotics in the European Union. Answer to the Request from the European Commission for Updating the Scientific Advice on the Impact on Public Health and Animal Health of the Use of Antibiotics in Animals European Medicines Agency. 2019. Available online: https://www.ema.europa.eu/en/documents/report/categorisation-antibioticseuropean-union-answer-request-european-commission-updating-scientific_en.pdf (accessed on 15 March 2020).

158. Frossling, J.; Wahlstrom, H.; Agren, E.C.; Cameron, A.; Lindberg, A.; Sternberg Lewerin, S. Surveillance system sensitivities and probability of freedom from Mycobacterium avium subsp. paratuberculosis infection in Swedish cattle. Prev. Vet. Med. 2013, 108, 47-62. [CrossRef] [PubMed]

159. Lindberg, A.; Brownlie, J.; Gunn, G.J.; Houe, H.; Moennig, V.; Saatkamp, H.W.; Sandvik, T.; Valle, P.S. The control of bovine viral diarrhoea virus in Europe: Today and in the future. Rev. Sci. Tech. 2006, 25, 961-979. [CrossRef] [PubMed]

160. European Commission. Farm to Fork Strategy for a Fair, Healthy and Environmentally-Friendly Food System; European Commission: Brussels, Belgium, 2020.

161. FAO. Tackling Antimicrobial Use and Resistance in Pig Production: Lessons Learned from Denmark; Food and Agricultural Organization of the United Nations, Ministry of Environment and Food of Denmark, Danish Veterinary and Food Administration: Rome Italy, 2019. Available online: http:/ / www.fao.org/documents/card/en/c/CA2899EN/ (accessed on 16 March 2020).

162. IAASTD. Agriculture at a Crossroads; Global Report; International Assessment of Agricultural Knowledge, Science and Technology for Development: Washington, DC, USA, 2009. Available online: http://apps.unep.org/redirect.php?file= /publications / pmtdocuments /-Agriculture\%20at\%20a\%20crossroads\%20-\%20Synthesis\%20report-2009Agriculture_at_ Crossroads_Synthesis_Report.pdf (accessed on 20 April 2019).

163. Kruse, A.B.; Kristensen, C.S.; Rosenbaum Nielsen, L.; Alban, L. A register-based study on associations between vaccination, antimicrobial use and productivity in conventional Danish finisher pig herds during 2011 to 2014. Prev. Vet. Med. 2019, 164, 33-40. [CrossRef]

164. Carlsson, U.; Wallgren, P.; Renstrom, L.H.; Lindberg, A.; Eriksson, H.; Thoren, P.; Eliasson-Selling, L.; Lundeheim, N.; Norregard, E.; Thorn, C.; et al. Emergence of porcine reproductive and respiratory syndrome in Sweden: Detection, response and eradication. Transbound. Emerg. Dis. 2009, 56, 121-131. [CrossRef]

165. Frossling, J.; Agren, E.C.; Eliasson-Selling, L.; Lewerin, S.S. Probability of freedom from disease after the first detection and eradication of PRRS in Sweden: Scenario-tree modelling of the surveillance system. Prev. Vet. Med. 2009, 91, 137-145. [CrossRef]

166. Swedish Poultry Meat Association. Antibiotika-statistik för Svensk Kyckling 2020. Available online: https://svenskfagel.se/ policyer/antibiotika / (accessed on 22 May 2020).

167. Wallgren, P.; de Verdier, K.; Sjölund, M.; Zoric, M.; Hultén, C.; Ernholm, L.; Persson Waller, K. Hur Mycket Kostar Sjukdomar för Lantbrukets Djur? Rapport SJV, Anslag 1:7. National Veterinary Institute 2012. Available online: https://www.sva.se/media/ xfikjusg/rapport_sjukdomskostnader-lantbruket-del-1_2013.pdf (accessed on 23 March 2020).

168. Andersson, H.; Lexmon, A.; Robertsson, J.A.; Lundeheim, N.; Wierup, M. Agricultural policy and social returns to eradication programs: The case of Aujeszky's disease in Sweden. Prev. Vet. Med. 1997, 29, 311-328. [CrossRef]

169. Hult, L.; Lindberg, A. Experiences from BVDV control in Sweden. Prev. Vet. Med. 2005, 72, 143-148; discussion 215-219. [CrossRef]

170. Ehlorsson, C.J.; Wallgren, P. (Eds.) Cost-benefit of eradication swine dysentery in a farrow-to-finish herd. In 10th European Symposium of Porcine Health Management 2018; European College of Porcine Health Management: Barcelona, Spain, 2018.

171. Engvall, A.; Andersson, Y.; Cerenius, F. (Eds.) The economics of the Swedish Salmonella control- A cost-benefit analysis. In NVI/WHO International Course on Salmonella Control in Animal Production and Products, A Presentation of the Swedish Salmonella Programme; WHO: Geneva, Switzerland, 1994.

172. Sundstrom, K.; Wahlstrom, H.; Ivarsson, S.; Lewerin, S.S. Economic effects of introducing alternative Salmonella control strategies in Sweden. PLoS ONE 2014, 9, e96446. [CrossRef] [PubMed]

173. De Briyne, N.; Atkinson, J.; Pokludova, L.; Borriello, S.P.; Price, S. Factors influencing antibiotic prescribing habits and use of sensitivity testing amongst veterinarians in Europe. Vet. Rec. 2013, 173, 475. [CrossRef] [PubMed]

174. Waller, K.P.; Hardemark, V.; Nyman, A.K.; Duse, A. Veterinary treatment strategies for clinical mastitis in dairy cows in Sweden. Vet. Rec. 2016, 178, 240. [CrossRef] [PubMed] 
175. Fischer, K.; Sjostrom, K.; Stiernstrom, A.; Emanuelson, U. Dairy farmers' perspectives on antibiotic use: A qualitative study. J. Dairy. Sci. 2019, 102, 2724-2737. [CrossRef]

176. DG-SANTE. Final Report of a Fact-Finding Mission Carried ut i Sweden from 10 October 2017 to 18 October 2017 in Order to Gather Information on the Prudent Use of Antimicrobials in Animals; European Commission, Directorate General for Health and Food Safety: Trim, Ireland, 2018. Available online: https: / $/ w w w \cdot g o o g l e . s e / u r l ? s a=t \& r c t=j \& q=\& e s r c=s \& s o u r c e=w e b \& c d=$ \&ved=2ahUKEwjHr_2Wm6LqAhVok4sKHcceBOQQFjABegQIBRAB\&url=https\%3A\%2F\%2Fec.europa.eu\%2Ffood\%2Fauditsanalysis\%2Fact_getPDF.cfm\%3FPDF_ID\%3D13639\&usg=AOvVaw2BXCU1D8Aih0-JNjX3DbDE (accessed on 15 March 2020).

177. WHO. NVI/WHO International Course on Salmonella Control in Animal Production and Products; World Health Organization, Veterinary Public Health Unit: Malmoö, Sweden, 1993. Available online: https://apps.who.int/iris/handle/10665/66448 (accessed on 15 March 2020).

178. Wierup, M. The experience of reducing antibiotics used in animal production in the Nordic countries. Int. J. Antimicrob. Agents 2001, 18, 287-290. [CrossRef]

179. Grave, K.; Jensen, V.F.; Odensvik, K.; Wierup, M.; Bangen, M. Usage of veterinary therapeutic antimicrobials in Denmark, Norway and Sweden following termination of antimicrobial growth promoter use. Prev. Vet. Med. 2006, 75, 123-132. [CrossRef]

180. Gavier-Widen, D.; Noremark, M.; Langeveld, J.P.; Stack, M.; Biacabe, A.G.; Vulin, J.; Chaplin, M.; Richt, J.A.; Jacobs, J.; Acin, C.; et al. Bovine spongiform encephalopathy in Sweden: An H-type variant. J. Vet. Diagn. Invest. 2008, 20, 2-10. [CrossRef]

181. EFSA. The European Union summary report on surveillance for the presence of transmissible spongiform encephalopathies (TSE) in 2018. EFSA J. 2019, 17, e05925. [CrossRef]

182. Lewerin, S.S.; Hallgren, G.; Mieziewska, K.; Berndtsson, L.T.; Chirico, J.; Elvander, M. Infection with bluetongue virus serotype 8 in Sweden in 2008. Vet. Rec. 2010, 167, 165-170. [CrossRef]

183. Chenais, E.; Stahl, K.; Frossling, J.; Blomqvist, G.; Naslund, K.; Svensson, L.; Renstrom, L.; Mieziewska, K.; Elvander, M.; Valarcher, J.F. Schmallenberg Virus beyond Latitude 65 degrees N. Transbound. Emerg. Dis. 2015, 62, e11-e18. [CrossRef]

184. Blancou, J. History of the Surveillance and Control of Transmissible Animal Diseases; Office International des Epizooties (OIE): Paris, France, 2003.

185. WHO. Impacts of Antimicrobial Growth Promoter Termination in Denmark; World Health Organization: Geneva, Switzerland, 2002. Available online: http:/ / www.who.int/iris/handle/10665/68357 (accessed on 15 March 2020).

186. EU. Regulation (EU) 2016/429 of the European Parliament and of the Council of 9 March 2016 on Transmissible Animal Diseases and Amending and Repealing Certain Acts in the Area of Animal Health ('Animal Health Law'). 2016. Available online: https: / / eur-lex.europa.eu/legal-content/EN/TXT/?uri=uriserv\%3AOJ.L_.2016.084.01.0001.01.ENG (accessed on 12 February 2020).

187. EU. Regulation (EU) 2019/6 of the European Parliament and of the Council of 11 December 2018 on Veterinary Medicinal Products and Repealing Directive 2001/82/EC. 2018. Available online: https:/ / eur-lex.europa.eu/eli/reg/2019/6/oj (accessed on 12 February 2020).

188. European Commission. Commission Implementing Decision of 26 June 2017 Concerning, in the Framework of Article 35 of Directive 2001/82/EC of the European Parliament and of the Council, the Marketing Authorisations for Veterinary Medicinal Products Containing "Zinc Oxide" to be Administered Orally to Food Producing Species. 2017. Available online: https:/ / ec.europa.eu/health/ documents / community-register/2017 /20170626136754/dec_136754_en.pdf (accessed on 12 February 2020). 